NBER WORKING PAPER SERIES

\title{
HIRES AND SEPARATIONS IN EQUILIBRIUM
}

\author{
Edward P. Lazear \\ Kristin McCue \\ Working Paper 23059 \\ http://www.nber.org/papers/w23059 \\ NATIONAL BUREAU OF ECONOMIC RESEARCH \\ 1050 Massachusetts Avenue \\ Cambridge, MA 02138 \\ January 2017
}

Any opinions and conclusions expressed herein are those of the authors and do not necessarily represent the views of the U.S. Census Bureau or the National Bureau of Economic Research. James Spletzer contributed to an earlier version of this paper. All results have been reviewed to ensure that no confidential information is disclosed. We thank Lucia Foster and John Haltiwanger for comments on an earlier version of this paper.

NBER working papers are circulated for discussion and comment purposes. They have not been peer-reviewed or been subject to the review by the NBER Board of Directors that accompanies official NBER publications.

(C) 2017 by Edward P. Lazear and Kristin McCue. All rights reserved. Short sections of text, not to exceed two paragraphs, may be quoted without explicit permission provided that full credit, including $($ ) notice, is given to the source. 
Hires and Separations in Equilibrium

Edward P. Lazear and Kristin McCue

NBER Working Paper No. 23059

January 2017

JEL No. E24,J01,M0,M00,M5

\begin{abstract}
$\underline{\text { ABSTRACT }}$
Hiring is positively correlated with separation, both across firms and over time. A theory of hiring and separation based on shifts in demand implies the opposite. One firm or industry hires and grows when another fires and contracts. But hiring for expansion and layoff for contraction comprises the minority of hiring and separation. A more accurate view is that hiring and separation reflect churn and are balanced in equilibrium, where one is the mirror image of the other. Hiring occurs primarily to fill vacant slots that open up when a firm separates a worker. Equivalently, a separation results when a worker is hired away by another firm. A model of efficient mobility yields several specific predictions in addition to the positive correlation between hires and separations. Labor market churn is most likely in firms and industries with low mean wages and high wage variance. Additionally, churn decreases during recessions with hires falling first followed by a decline in separations to match hiring. Finally, the young are predicted to bear the brunt of hiring declines. These predictions are borne out in the LEHD microdata at the economy and firm levels.
\end{abstract}

Edward P. Lazear

Graduate School of Business

Stanford University

Stanford, CA 94305

and Hoover Institution

and also NBER

lazear@stanford.edu

Kristin McCue

U.S. Census Bureau

$\mathrm{CES} / 2 \mathrm{~K} 130 \mathrm{E}$

4600 Silver Hill Rd

Washington DC 20233-6300

kristin.mccue@census.gov 
How do firms decide how many workers to hire and fire? Among the key issues in personnel economics, none is more important than understanding the factors behind hiring and separation decisions. As has been discussed in earlier papers, much of hiring and separation reflects churn. ${ }^{1}$ Churn is defined as simultaneous hiring and separation by the same employer. Data from the Longitudinal Employer Household Dynamics (LEHD) reveal that almost threequarters of hiring and of separation is churn, not expansion or contraction. Therefore, to understand hiring and separation it is necessary to understand churn and its determinants. The fact that churn is so important means that to a large extent, hires and separations are mirror images of one another. Churn hiring is about worker replacement, rather than changes in firm size. $^{2}$

The view adopted here is that hiring and separation move workers to their most efficient use, taking into account the cost of turnover. A worker is hired away from a firm when the expected value of alternatives elsewhere exceeds the value to the current employer by more than the transaction cost of moving. Put differently, but equivalently in equilibrium, a firm separates a worker when that worker's productivity is lower than the expected productivity of a new hire, net of hiring costs. Workers are hired to replace those who have quit, been fired, or retire. Firms allow workers to leave when output gain from keeping the worker falls short of filling the slot with a new hire. Consequently, to understand hiring, it is important to understand the

\footnotetext{
${ }^{1}$ There already exists a literature that documents the empirical relation of churn to total hiring. Early papers that lay the groundwork for the empirical logic employed below are Davis and Haltiwanger (1992), Hamermesh, Hassink, and Van Ours (1996) and Albaek and Sorensen (1998). They examine the proportion of hires that occur in firms with decreasing or constant employment, added to the separations in firms with expanding employment. Burgess, Lane and Stevens $(2000,2001)$ focus directly on churn hiring as a proportion of the total. The authors make the point that most job flows are accounted for by churn. Picot, Heisz and Nakamura (2000) perform a similar exercise using Canadian data. Abowd, Corbel and Kramarz (1999) use French data to examine the relation of skill level to hiring and separation, and find simultaneous entry and exit is a decreasing function of skill level. Lazear and Spletzer (2012) document the variation over the business cycle.
} 
determinants of separation, and vice versa. Specifically, differences in hiring rates, or equivalently, separation rates, over time and across employers must be related to differences in the cost of and benefits from reallocation of workers, both over time and across employers.

There are two potential questions with respect to hiring. The first, which is the subject of this analysis is "how many workers does a firm choose to hire in any given time period?" The second, which is not addressed here, is "how does a firm choose which workers to hire once the number of hires has been determined?" To understand the determinants of hiring and separating, it is essential to be able to explain how churn varies by industry, firm and worker type. To understand the determinants of employment growth or contraction, or of changes in firm size, churn is irrelevant. Churn has no effect on changes in employment. The goal here is to explain hiring and separation that are associated with churn rather than to explain changes in employment at the economy level or the size distribution of firms.

The main point that links hiring to separation was made a couple of decades ago in the context of layoff restrictions, especially in European countries. In Lazear (1990) and Bentolila and Bertola (1990), it was argued and demonstrated empirically that requiring firms to offer severance pay when a worker is separated has an adverse effect on hiring. Firms are reluctant to hire workers whom they cannot fire. ${ }^{3}$ The fact that a hiring decision sometimes needs to be reversed necessitates separation and replacement, which implies that hiring rates are low when separation costs are high.

\footnotetext{
${ }^{3}$ The emphasis here, both at the conceptual and empirical level, is the opposite of that in Faberman and Nagypal (2008). They focus on expansion and contraction hiring and model transitions from one firm to another that occur when one firm experiences a shock in productivity (or demand) relative to others in the economy. As a result, workers move from one firm to another and the convex mobility costs place a limit on that movement. Here, the story is about churn, not expansion or contraction hiring. The argument is that expansion and contraction are a relatively minor part of the story and to understand hiring and firing, sorting of workers to various firms is crucial. Churn occurs when a worker (not the entire firm) is idiosyncratically better suited to another firm and moves. The matching framework, originally introduced by Jovanovic (1979), is better suited to explaining this phenomenon.
} 
The emphasis in this analysis differs from earlier work in two respects. First, much of the focus is on providing theory that links hiring to separation. Second, using employer-level data on hiring and separation, the theory is tested and applied across employers and over time. Variations in the costs and benefits of worker mobility are the key drivers.

Let us begin with a few basic facts from the published Job Openings and Labor Turnover Survey (JOLTS) data. During the average quarter between 2001 and 2014, 13.35 million workers were hired and 13.16 million workers were separated from their jobs. The average absolute change in net employment was small by comparison, at 556,000 per quarter. ${ }^{4}$ The time $^{2}$ series correlation between aggregate hiring and separations is about .88 , suggesting that hiring and separations move together closely. The same pattern is observed if the data are broken down by industry. Each industry experiences significant hiring and separation, but the net is small relative to the gross and the time series correlations by industry tend to be quite positive. The well-known work by Davis, Faberman, and Haltiwanger (2006) has already documented this pattern. ${ }^{5}$ Lazear and Shaw (2009) report that high rates of turnover are pervasive not only in the U.S., but in all other developed economies studied. Slow recoveries are associated with low

\footnotetext{
${ }^{4}$ This is the average absolute value of the seasonally adjusted change in employment. Without seasonal adjustment, the average absolute value is 990,000 .

${ }^{5}$ Davis, Faberman and Haltiwanger (2006) discuss the nature of net flows to gross flows, but earlier work by Davis and Haltiwanger (1992) and by Anderson and Meyer (1994) also speaks to this point. Anderson and Meyer find that a significant fraction of separations are temporary, followed by a subsequent recall. This has been documented more recently by Fujita and Moscarini (2013), who find that a large fraction of workers who separate during recessions regain employment with their previous employers. That is not what is meant by churn here because a recall implies that the worker is well-suited to the firm from which he was recently separated. Using the LEHD data, we find that eliminating recalls defined as workers returning to their prior firm within one quarter after separation reduces the churn rate from 0.161 to 0.147 , the hiring rate from 0.236 to 0.213 and the separation rate from 0.248 to 0.225 over the period 1998Q2:2015Q3. The main predictions of the theory and findings are not affected by this redefinition.
} 
levels of hiring. ${ }^{6}$ But the majority of hiring and separation reflects churn, not expansion or contraction.

Additionally, some industries and employers have persistently high hire and separation rates, whereas other employers and industries have low hire and separation rates. For example, in the LEHD data, the hiring rate in construction is $31.6 \%$ and the hiring rate in manufacturing is $11.3 \%$. Furthermore, employer fixed effects explain 44 percent of the variation in hire, separation, and churn rates. ${ }^{7}$ This suggests that the cost and benefit of hiring and separating workers varies across establishments and industries and that those costs are important factors in explaining the patterns observed.

In what follows, a theory of churn is presented. The main theoretical results are that hires and separations are positively correlated. The positive cross-sectional correlation results because the costs and benefits of sorting workers to the most efficient use differ by firm and industry. The time-series correlation results because active labor markets like those during cyclic expansions have more workers, particularly young, who need to be matched efficiently. This implies that churn is pro-cyclic (one of the main findings of Lazear and Spletzer (2012)), that hires lead separations during recessions, and that decreases in employment during recessions are borne disproportionately by young workers. Hires lead separations during recessions because a decline in demand decreases the optimal number of new workers, which implies fewer hires. However, the existing stock of senior workers still needs to be sorted to firms at which their

\footnotetext{
${ }^{6}$ See Hall (2011). See Lazear and Spletzer (2012) for a discussion of the relation of hiring and separation rates to net employment growth over the business cycle. When the economy declines, churn turns into employmentreducing separations as departing workers are not replaced. Increases in net employment growth, from large negative levels to somewhat positive levels between 2009 and 2011, reflect a decline in layoffs rather than a rise in hiring, which the JOLTS data make clear.

${ }^{7}$ This is without controlling for industry, so includes both within and between industry variation. For the churn rate, employer fixed effects account for only 10 percent of the variation when single-quarter jobs are excluded.
} 
productivity is high so the number of separations remain high until the size of the labor force adjusts.

Furthermore, hires, separations and churn are all related to the level and variance in wages. These predictions are confirmed with the LEHD data, as is the primary finding that churn accounts for a large fraction of hiring and separations, even at the level of the employer.

\section{The Model}

The model used allows hiring and separation to allocate workers to their most productive uses. Separation is modeled to be efficient and the theory abstracts from the distinction between quits and layoffs. ${ }^{8}$ Further, the model ignores unemployment and concentrates primarily on the number of separations and hires, rather than on the amount of time that it takes to find a job. Other models, including those that generate mobility as a result of rent seeking behavior, may have similar implications. For the purposes here, that is of no consequence. The analysis neither requires nor tests efficiency in labor market. The purpose is instead to emphasize the role of churn in labor markets. A model of efficient matching is sufficient, although perhaps not necessary, to generate the observed behavior.

The structure is of the standard overlapping-generations type. The model is highly stylized, but captures the essence of churn separation and hiring. Workers join the labor force when young, retire when old, and seek to find more suitable employment in the middle. Specifically, in every period, $\mathrm{N}$ workers are born, and each lives for two periods. Every firm, of which there are $2 \mathrm{~N}$, employs one worker, exhausting the full supply of labor. In any period there

\footnotetext{
8 As modeled, separation is efficient, so the difference between a quit and layoff seems vacuous. As economists know, a layoff can be turned into a quit by adjusting the wage appropriately, and vice versa. See McLaughlin (1991), who was among the first to investigate the distinction between quits and layoffs. The empirical work focuses on total separations, since the LEHD data has no information on quits versus layoffs.
} 
are $2 \mathrm{~N}$ workers, half of whom are young and half are old. There is full employment in each period. Unemployment, or rather reduced employment, works through a decrease in labor force participation, where $\mathrm{N}$ declines.

The production function is one of extreme diminishing productivity. Output of the first worker is a random variable because workers vary in their productivity. To make this simple, output of a second worker is zero, say, because each firm (optimally) has only one machine and production requires the combination of a worker and a machine.

The assumption of one-worker firms is a mere modeling convenience. Firms could have multiple workers and there could be fewer than $2 \mathrm{~N}$ firms in the economy. An alternative and equivalent structure is to assume the existence of two firms, $\mathrm{i}$ and $\mathrm{j}$, each with $\mathrm{N}$. Essential is that worker productivity has a component that differs across firms and the differences in productivity induce mobility.

Each firm faces the same distribution of worker productivity. A worker's productivity in firm $\mathrm{i}$ is $\mathrm{V}_{\mathrm{i}}$ and in firm $\mathrm{j}, \mathrm{i} \neq \mathrm{j}$, is $\mathrm{V}_{\mathrm{j}} . \mathrm{V}_{\mathrm{i}}$ and $\mathrm{V}_{\mathrm{j}}$ are defined as

(1) $\quad V_{i}=V+\varepsilon_{i} \quad$ and $\quad V_{j}=V+\varepsilon_{j}$

where $\varepsilon_{\mathrm{i}}$ and $\varepsilon_{\mathrm{j}}$ are i.i.d., each being governed by the density functions and distribution functions $\mathrm{f}(\varepsilon)$ and $\mathrm{F}(\varepsilon)$, respectively. ${ }^{9}$

A worker's productivity is unknown when he joins the firm. After one period, productivity at the current firm is known to be equal to $\mathrm{V}_{\mathrm{i}}$, but productivity in the other firms

\footnotetext{
9 At this point, $\mathrm{V}$ could be assumed to be equal to zero, but it will be useful to allow it to take on other values later to consider expansion, contraction, and business cycle effects.
} 
remains unknown because $\varepsilon_{\mathrm{i}}$ and $\varepsilon_{\mathrm{j}}$ are i.i.d. When the worker is middle-aged, he receives one and only one offer from another firm, $\mathrm{j}$.

Let the cost of hiring be given by $\eta$. Efficient separation ${ }^{10}$ implies that a middle-aged worker, i.e., one who has worked one period, should leave his current firm i and move to a different firm $\mathrm{j}, \mathrm{i} \neq \mathrm{j}$, when the expected output, net of hiring cost, exceeds $V_{i}$, or when

$$
V+\varepsilon_{i}<E\left(V_{j}\right)-\eta
$$

Using (1), the condition for efficient separation can be written as

$$
\text { (2') } \quad \varepsilon_{\mathrm{i}}<-\eta
$$

The probability that a middle-aged worker is separated is therefore $F(-\eta)$. Consequently, in each period, $\mathrm{N}$ workers retire and $\mathrm{N} \mathrm{F}(-\eta)$ workers separate because their output at their current firm is lower than the expected output, net of turnover costs, at the alternate firm. The expected number of separations in any period is then

$$
S=N(1+F(-\eta))
$$

Consider firms' replacement hiring. Each period $\mathrm{N}$ workers retire, creating $\mathrm{N}$ job openings. At the same time, $\mathrm{N} \mathrm{F}(-\eta)$ of the middle-aged workers separate from their firms creating another $\mathrm{N} \mathrm{F}(-\eta)$ job openings. The number of workers available to be hired consists of $\mathrm{N}$ new entrants to the labor market, plus the $\mathrm{N} \mathrm{F}(-\eta)$ middle-aged workers who separated from their firms. The number of job openings equals the number of workers available for hire and, absent frictions, the number of hires is therefore

10 This structure derives from the basic matching model, first set out in Jovanovic (1979). 


$$
H=N(1+F(-\eta))=S
$$

Hiring occurs to replace workers who separate efficiently. The condition in (2), that workers separate when their expected productivity, net of turnover costs, is greater elsewhere than at the current firm, is equivalent to stating that separation occurs to make room for a worker who is expected to be better than the incumbent. A firm chooses to hire for replacement when the incumbent is less productive than the expected value of the replacement, net of turnover costs, or when

$$
\mathrm{V}+\varepsilon_{\mathrm{i}}<\mathrm{E}\left(\mathrm{V}_{\mathrm{i}}\right)-\eta
$$

Because $\mathrm{E}\left(\mathrm{V}_{\mathrm{i}}\right)=\mathrm{V}$, the condition is

$$
\varepsilon_{\mathrm{i}}<-\eta
$$

This is the same as $\left(2^{\prime}\right)$. One can think of hiring as occurring for the purpose of replacement or of separation as occurring to allow new hiring. They are equivalent. Both phenomena reflect movement of labor to their most efficient use and it is variations in $\eta$ and in $F(\varepsilon)$ that drive both. ${ }^{11}$

It follows immediately from equation (4) that

$$
\partial H / \partial \eta=\partial S / \partial \eta=-N f(-\eta)
$$

\footnotetext{
${ }^{11}$ To be accurate, it should be noted that the number hired and separated in the economy is a random variable, not a deterministic number. As a consequence, there will always be some amount of non-matching, leaving some vacancies and unemployed workers.
} 
which is negative. An increase in the cost of hiring, $\eta$, leads to a decrease in the number of hires and separations. This works through a decrease in churn of middle-aged workers.

Equations (4) and (5) describe the primary features of the labor market. First, hires equal separations, both for the labor force as a whole and for each particular firm. The model so far is one of pure churn, where all firms remain at their initial size. Although this is obviously not realistic, it is not too far-fetched since, as documented below, roughly 75 percent of quarterly hires and separations in the LEHD microdata reflects churn. Second, the amount of hiring and separation depends on the cost of turnover, $\eta$, and on the shape of the productivity distribution function, $F(\varepsilon)$. Industries or firms with a high $\eta$ should exhibit less churn. The empirical work below analyzes how churn varies across individual and job characteristics that proxy for the cost of hiring. Additionally, because the amount of mobility at middle age equals N F(- $\eta$ ), the shape of the productivity distribution $\mathrm{F}(\varepsilon)$ also determines mobility. As discussed in more detail in the empirical section, a fatter lower tail to the distribution implies more churn. ${ }^{12}$

\section{Labor Market Structure}

The existence of a turnover cost, $\eta$, means that an alternative firm is at a disadvantage relative to the current firm. Does this create the possibility of inefficient separation? For inefficient separation to occur, it would be necessary either for the wage to be too low to retain the worker when retention is efficient or for the wage to be so high that the firm chooses to fire the worker when he should be retained.

12 The efficient separations model and the resulting separation probability $F(-\eta)$ are not new, but novel here is a focus on how the distribution of productivity affects the probability of separation. 
First consider whether the wage can be so low that the worker quits even when it is inefficient to do so. Inefficient separation is defined as separation when $V+\varepsilon_{i}>V+E\left(\varepsilon_{j}\right)-\eta$ or when $\varepsilon_{\mathrm{i}}>-\eta$. Now, the current firm is always willing to pay up to $\mathrm{V}+\varepsilon_{\mathrm{i}}$. An alternative firm $\mathrm{j}$ can never pay more than $\mathrm{V}-\eta$. For firm $\mathrm{j}$ to offer enough to attract the worker, it would have to be the case that $V-\eta>V+\varepsilon_{i}$ or that $\varepsilon_{\mathrm{i}}<-\eta$, which violates the requirement for inefficient separation.

It is also impossible that the wage is bid so high that the firm fires the worker when it is inefficient to do so. The alternative firm will pay no more than $\mathrm{V}-\eta$ and the current firm will retain the worker as long as productivity exceeds the wage, which means the current firm will pay up to $\mathrm{V}+\varepsilon_{\mathrm{i}}$. For the wage to be so high that the firm would fire the worker, it would have to be the case that $V-\eta>V+\varepsilon_{\mathrm{i}}$ or that $\varepsilon_{\mathrm{i}}<-\eta$ which, again, violates the definition of inefficient separation.

The converse is also true. Separation always occurs when it is efficient. A separation is efficient when $\varepsilon_{\mathrm{i}}<-\eta$. The maximum wage that the current firm can pay is $\mathrm{V}+\varepsilon_{\mathrm{i}}$. An alternative firm can pay up to $\mathrm{V}-\eta$. Thus, a worker will quit whenever the outside wage exceeds the maximum current wage or whenever $\mathrm{V}-\eta>\mathrm{V}+\varepsilon_{\mathrm{i}}$, which is the same as whenever $-\eta>\varepsilon_{\mathrm{i}}$. But if $-\eta>\varepsilon_{i}$, then separation is efficient by (2'). Thus, a competitive labor market ensures efficient turnover even when hiring costs create a wedge between the amount that the current firm and others can pay. ${ }^{13}$

\footnotetext{
13 This result also holds in the presence of bargaining. The productivity of a given middle aged worker is $\mathrm{V}+\varepsilon_{\mathrm{i}}$, but the alternative firm can offer at most $V-\eta$. Consequently, allowing $\lambda$ to be the rent-sharing parameter that results from whatever bargaining game characterizes the negotiation with $0 \leq \lambda \leq 1$, the wage of a worker who stays is given by $\lambda\left(\mathrm{V}+\varepsilon_{\mathrm{i}}\right)+(1-\lambda)(\mathrm{V}-\eta)$, or Wage of a stayer $=\mathrm{V}-\eta+\lambda\left(\varepsilon_{\mathrm{i}}+\eta\right)$.
} 


\section{Churn, Expansion, and Contraction}

The model can be extended to allow for expansion hiring and contraction separation as well as churn. This is introduced via a neutral demand shock, in which all firms experience an increase or decrease in demand, say, during recessions or recoveries.

What happens when the demand for labor changes, say, as a result of a shock that causes a downturn in economic activity? This implies a change in the value of $\mathrm{V}$, which shifts the distribution of values in all firms identically.

The decline in demand affects the equilibrium number worked because the decline reduces the value of work and therefore the number of workers who opt to enter the workforce. In the context of the current model, this takes the form of changes in the number "born" each period, which was previously assumed to be exogenously fixed at N. Instead, let the per-period alternative value of time be given by $A$ with density $\mathrm{g}(A)$ and with distribution function $\mathrm{G}(A)$. A person enters the workforce if the two-period expected earnings exceed two periods of alternative value, ${ }^{14}$ or if ${ }^{15}$

$$
2 A<[\mathrm{V}-\eta+\mathrm{V}+\mathrm{E}(\varepsilon \mid \varepsilon>-\eta)](1-\mathrm{F}(-\eta))+[2(\mathrm{~V}-\eta)] \mathrm{F}(-\eta)
$$

\footnotetext{
Workers who stay at their job have $\varepsilon_{\mathrm{i}}>-\eta$, and thus the wage of a stayer can never be below the alternative offered wage of $\mathrm{V}-\eta$. Alternative firms can never outbid the current firm.

${ }_{14}$ The per-period expected value of entering for the entire lifetime exceeds the value of entering for only one period so the possibility of entering at mid-life is ignored. To avoid having some individuals drop out of the labor force at middle age (and some job leavers might opt to do so), it is assumed that once the decision is made when young to enter the labor force, the non-market alternative $A$ depreciates to zero. It is possible to allow some retirement among those who are unlucky in their first industry, but doing so adds notation without any particular insight, merely enlarging the retirement pool and the amount of replacement hiring. The empirical work below examines the age pattern of the entering and exiting cohorts across the business cycle.

${ }^{15}$ For simplicity of notation, it is assumed that all rents go to the worker. But any rule that divides rent in a consistent fashion across states of the world yields identical implications.
} 
There is a $1-F(\eta)$ probability that the worker stays in the initial firm, receiving $V-\eta$ as a young worker and the expected wage

$$
\mathrm{V}+\mathrm{E}(\varepsilon \mid \varepsilon>-\eta)
$$

as an older worker and $\mathrm{V}-\eta$ as a young worker. There is a $\mathrm{F}(-\eta)$ probability that the worker moves to a different firm, bearing hiring costs and receiving wage $V-\eta$ in both stages of life.

Define

$$
\mathrm{V}^{\mathrm{s}} \equiv \mathrm{V}+\mathrm{E}(\varepsilon \mid \varepsilon>-\eta)
$$

$\mathrm{V}^{\mathrm{s}}$ is the expected value of workers who stay at their initial firm when old. Then the entry condition can be written as

$$
A<1 / 2\left(\mathrm{~V}-\eta+\mathrm{V}^{\mathrm{s}}\right)(1-\mathrm{F}(-\eta))+(\mathrm{V}-\eta) \mathrm{F}(-\eta)
$$

so

$$
\mathrm{G}\left[1 \frac{1}{2}\left(\mathrm{~V}-\eta+\mathrm{V}^{\mathrm{s}}\right)(1-\mathrm{F}(-\eta))+(\mathrm{V}-\eta) \mathrm{F}(-\eta)\right]
$$

is the probability that a person enters the labor force.

To be consistent with the previous analysis, $\mathrm{N}$ must satisfy

$$
N=(\text { Cohort size }) G\left[1 / 2\left(V-\eta+V^{s}\right)(1-F(-\eta))+(V-\eta) F(-\eta)\right]
$$

because this is the number of young individuals (each period) who have $A$ below the expected value of work.

Given that supply is now endogenous, consider what happens when demand falls. A decrease in demand is modeled as a decline in worker expected value from $\mathrm{V}$ to $\mathrm{V}^{*}$, which could 
occur, say, because of recession that results in a decline in world demand for a country's output. Using (6) and defining

$$
\mathrm{V}^{\mathrm{s}^{*}} \equiv \mathrm{V}^{*}+\mathrm{E}(\varepsilon \mid \varepsilon>-\eta)
$$

the new number of entrants to the labor market is

$$
\mathrm{N}^{*}=(\text { Cohort size }) \mathrm{G}\left[\frac{1}{2}\left(\mathrm{~V}^{*}-\eta+\mathrm{V}^{\mathrm{s}^{*}}\right)(1-\mathrm{F}(-\eta))+\left(\mathrm{V}^{*}-\eta\right) \mathrm{F}(-\eta)\right]
$$

Because $\mathrm{V}>\mathrm{V}^{*}$ and $\mathrm{G}^{\prime}$ is positive, $\mathrm{N}>\mathrm{N}^{*}$. The decrease in the value of work lowers the number of young workers who decide to enter the labor force. ${ }^{16}$ Since supply must equal demand, the decrease in hiring of young workers is

$$
\begin{array}{r}
\mathrm{N}-\mathrm{N}^{*}=(\text { Cohort size })\left\{\mathrm{G}\left[1 / 2\left(\mathrm{~V}-\eta+\mathrm{V}^{\mathrm{s}}\right)(1-\mathrm{F}(-\eta))+(\mathrm{V}-\eta) \mathrm{F}(-\eta)\right]-\right. \\
\left.\mathrm{G}\left[1 / 2\left(\mathrm{~V}^{*}-\eta+\mathrm{V}^{\mathrm{s}^{*}}\right)(1-\mathrm{F}(-\eta))+\left(\mathrm{V}^{*}-\eta\right) \mathrm{F}(-\eta)\right]\right\} .
\end{array}
$$

What happens to hires and separations during the recession? The economy requires several periods to transition from the initial level of employment of $2 \mathrm{~N}$ to the new level of employment of $2 \mathrm{~N}^{*}$. Hiring during the initial recession period consists of replacing the middleaged workers who move to other firms and new hires from the entering cohort, or

(7) Hires during initial recession period $=N^{*}+F(-\eta) N$.

${ }^{16}$ The decrease in the value of each worker from $\mathrm{V}$ to $\mathrm{V}^{*}$ does not change the separation probability $\mathrm{F}(-\eta)$ for middle aged workers. A middle-aged worker changes jobs if $\mathrm{V}^{*}+\varepsilon_{\mathrm{i}}<\mathrm{V}^{*}-\eta$, which is the efficient separation equation (2). 
During subsequent recession periods, replacement hiring declines as a result of a decline in the size of entering cohorts who become middle aged, and total hiring is

(8) Hires during recession equilibrium $=\mathrm{N}^{*}(1+\mathrm{F}(-\eta))$.

Separations during the initial recession period consists of those who retire plus middleaged workers who move to other firms, or

(9) Separations during initial recession period $=N(1+F(-\eta))$.

After final adjustment, separations equal ${ }^{17}$

(10) Separations during recession equilibrium $=N^{*}(1+F(-\eta))$.

Equations (7) - (10) provide implications for the pattern of hiring and separations over a business cycle. The dynamics of hires and separations from the pre-recessionary levels to the levels that occur during the recession are shown in Figure 1. The time series pattern shows separations exceeding hires during the transition into recession, which is necessary for employment to decline from $2 \mathrm{~N}$ to $2 \mathrm{~N}^{*} \cdot{ }^{18}$ The time series pattern in Figure 1 resembles that of the hires and separations published from the JOLTS data during the 2007-2009 recession (see Chart 3 of http://www.bls.gov/web/jolts/jlt_labstatgraphs.pdf, as well as in Figure 1 of Lazear and Spletzer 2012). Figure 2, which graphs data from both JOLTS and LEHD and which is discussed below, also supports this prediction.

\footnotetext{
${ }^{17}$ There are also two transition periods for separations. The middle period has $\mathrm{N}^{*}$ middle aged workers changing jobs and $\mathrm{N}$ retirees, so separations in the middle period are $\mathrm{N}+\mathrm{F}(-\eta) \mathrm{N}^{*}$.

${ }_{18}$ The net employment change in each transition period is hires minus separations equal to $\mathrm{N}^{*}-\mathrm{N}$.
} 
Churn hiring occurs when a firm hires to replace a separating worker. Churn at the level of the firm is the minimum of hires and separations by that firm. In this model, for the economy as a whole, churn during the initial recession period is

(11) Churn during initial recession period $=\mathrm{N}^{*}+\mathrm{F}(-\eta) \mathrm{N}$.

During all subsequent recession periods, the level of churn is

(12) Churn during other recession periods $=\mathrm{N}^{*}(1+\mathrm{F}(-\eta))$.

Churn hiring declines when the economy goes from normal times to recession, from the level that prevails during normal times given by equation (4), to the interim level given by equation (11) to the new lower level in the low demand state, given by equation (12). The decline in the first period results from a fall in the size of the entering cohort, and the decline in the second period results from this smaller cohort reaching middle age and thus a smaller number of middle aged workers changing jobs.

Equations (7) - (12) and Figure 1, which is drawn to reflect them, provide a number of implications that are consistent with the facts. First, as mentioned above, churn is procyclic, falling from $\mathrm{N}(1+\mathrm{F}(-\eta))$ during normal times (eq. 4) to $\mathrm{N}^{*}(1+\mathrm{F}(-\eta))$ during recessions (eq. 12). This is documented below with the LEHD data, and is also one of the main findings of Lazear and Spletzer (2012). As the size of the workforce falls, fewer hires are made and fewer separations that move workers to more productive uses occur.

Second and related, hires and separations move together over the business cycle. During normal times, both hires and separations equal $\mathrm{N}(1+\mathrm{F}(-\eta))$ from (4). During the recessionary 
equilibrium, both hires and separations equal $\mathrm{N}^{*}(1+\mathrm{F}(-\eta))$ from $(8)$ and (10). Recall that $\mathrm{N}^{*}<\mathrm{N}$, which implies not only that there are fewer hires during recessions, but also, consistent with the facts, that there are fewer separations during recessions.

Third, although separations and hires are correlated over the business cycle, during the transition from normal times to the recessionary equilibrium, separations exceed hires. The logic is that when demand falls, optimal employment falls so hiring declines as fewer supply their services to the labor force. But initially, separation does not decline because separation occurs when expected productivity is enhanced by a move and a neutral decline in demand does not change the optimal sorting of workers to firms. Since workers separate when and only when it is efficient for them to move to another firm, there is no reason for a decline in demand to alter the separation rate. Given that the separation rate is the unaltered and that the stock of employed workers is determined by the economic conditions encountered by the prior cohort (not the one that experienced the demand decline), the number of separations initially remains unchanged.

From (7), hires during the initial recession period equal $\mathrm{N}^{*}+\mathrm{F}(-\eta) \mathrm{N}$, and from (9), separations during the initial recession period equal $N+F(-\eta) N$. During the second period of the transition to the recessionary equilibrium, hires are $\mathrm{N}^{*}+\mathrm{F}(-\eta) \mathrm{N}^{*}$ (see eq. 8) and separations are $\mathrm{N}+\mathrm{F}(-\eta) \mathrm{N}^{*}$. Since $\mathrm{N}^{*}<\mathrm{N}$, separations during the initial two periods of the recession exceed hires, which is by definition necessary for employment to decline during the recession. Again, this is consistent with the LEHD data as shown below and with the published JOLTS data.

Fourth, although there is no unemployment in this model (because supply equals demand), the young workers are the ones who bear the brunt of reductions in employment. During the initial period of the recession, employment among the middle age remains at $\mathrm{N}$, whereas 
employment among new entrants falls from $\mathrm{N}$ to $\mathrm{N}^{*}$. This is consistent with the published data that shows entry into the labor force is more cyclically sensitive for younger workers as shown later in figure 6.

Additional implications of the model can be checked using JOLTS and LEHD data. There is no unemployment in this framework so there are no implications for changes in unemployment over the business cycle. In this structure, unemployment takes the form of reduced labor force participation so it is more natural to look at the employment rate, which is defined as the proportion working relative to the working-age population, or

$$
\begin{array}{rlll}
\text { Employment Rate } & =\quad \mathrm{N} /(\text { cohort size }) & \text { during normal times } \\
& =\quad \mathrm{N}^{*} /(\text { cohort size }) & \text { during recessions }
\end{array}
$$

Because $\mathrm{N}^{*}<\mathrm{N}$, the employment rate falls during recessions. This is consistent with the evidence for all recessions for which data are available. The employment rate was at a high of $63.4 \%$ in 2007 and reached a low of $58.2 \%$ during the $2007-9$ recession.

It is also possible to examine the hire and separation rates. By construction, the model has hire and separation rates defined relative to the workforce remain constant, which is counterfactual. The data show that both hire and separation rates decline during recessions.

There is a sense in the context of this model in which the hire and separation rates fall during recessions. Because all unemployment works through changes in the number in the labor force, a more sensible definition of hire and separation rates uses the working age population rather than to the workforce as denominator. With this definition, the model does fit the facts, predicting that both hiring and separation rates relative to the population decline in recessions. 
Defining Population Hiring Rate as Hires / Number in the working age population, the model predicts

$$
\begin{aligned}
\text { Population Hire rate }= & N(1+F(-\eta)) / 2(\text { cohort size }) & \text { during normal times } \\
& =N^{*}(1+F(-\eta)) / 2(\text { cohort size }) & \text { during recessions }
\end{aligned}
$$

which is lower during recessions because $\mathrm{N}^{*}<\mathrm{N}$. Similarly, the Population Separation Rate

$$
\begin{aligned}
\text { Population Separation Rate } & =\mathrm{N}(1+\mathrm{F}(-\eta)) / 2(\text { cohort size }) & \text { during normal times } \\
& =\mathrm{N}^{*}(1+\mathrm{F}(-\eta)) / 2(\text { cohort size }) & \text { during recessions }
\end{aligned}
$$

also falls during recessions, which is observed in both JOLTS and LEHD. JOLTS data yield a population hiring rate of $8 \%$ during normal times, which falls to $6.1 \%$ during the recession.

\section{Hires, Separations, and Churn}

The empirical analysis begins with an examination of published hires and separations data. There are two sources of hires and separations data in the U.S.: the Job Openings and Labor Turnover Survey (JOLTS) and the Quarterly Workforce Indicators (QWI) which are constructed from the Longitudinal Employer Household Dynamics (LEHD) data.

JOLTS is a monthly survey of 16,000 establishments that collects data on hires, separations, and job openings. ${ }^{19}$ The JOLTS statistics on hires and separations from December 2000 to the present are available from the BLS website. The analysis here uses quarterly data

\footnotetext{
${ }^{19}$ For information on the JOLTS, see http://www.bls.gov/jlt/)
} 
created from the monthly JOLTS statistics, restricted to the private sector, with a time series that begins in 2001:Q1.

The Longitudinal Employer Household Dynamics (LEHD) data is a longitudinally linked employer-employee dataset created by the U.S. Census Bureau as part of the Local Employment Dynamics federal-state partnership. The data are derived from state-submitted Unemployment Insurance (UI) wage records and the Quarterly Census of Employment and Wages (QCEW) data, and are enhanced by the Census Bureau with information about the worker (age, gender, and education) and the firm (firm age and firm size). Abowd et al. (2009) provide a thorough description of the source data and the methodology underlying the LEHD data. The analysis in this section uses quarterly measures of hires and separations from the Quarterly Workforce

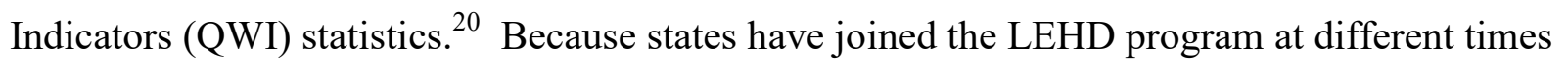
and have provided various amounts of historical data upon joining the LEHD program, the length of the time series of LEHD data varies by state. The data used here are private sector data from 29 states that have data available from 1998:Q2 through 2015:Q3. ${ }^{21}$

Figure 2 presents the seasonally adjusted time series of quarterly hires and separation rates from the JOLTS and the LEHD. ${ }^{22}$ The rates of hires and separations are clearly different across the two data sources, and all four series appear to exhibit a secular decline over the last 15 years, but these are not serious concerns for the analysis here. The different levels and trends in the two

\footnotetext{
${ }^{20}$ See http://lehd.ces.census.gov/data/\#qwi

${ }^{21}$ The 29 states in our sample are CA, CO, FL, GA, HI, ID, IL, IN, KS, LA, MD, ME, MN, MO, MT, NC, ND, NJ, NM, NV, PA, RI, SC, SD, TN, TX, VA, WA, and WV. These 29 states account for about 65 percent of national employment.

${ }^{22}$ The definition of hires and separations warrants mention. Hires and separations in the JOLTS are from the survey questionnaire found at http://stats.bls.gov/jlt/jltc1.pdf. Hires and separations in the LEHD refer to the appearance or disappearance of earnings for a worker-employer combination in the administrative records; see Abowd et.al. (2009). Hires and separations in both data sources are measured at the establishment level.
} 
data sources likely reflect the many short-duration jobs that are present in administrative data but not present in survey data. Hyatt and Spletzer (2013a) document that 40 percent of hires and separations in the LEHD in 1998:Q4 are person-employer matches that last less than one quarter. Analysis of the earnings data in the LEHD suggests that many of these short-duration jobs are quite short, with durations measured in days rather than weeks. The 40 percent statistic for 1998:Q4 falls to 33 percent in 2010:Q3, and this decline accounts for 53 percent of the twelve year decline of the LEHD hires and separation rates evident in Figure $2 .^{23}$

Important for an analysis of churn is the strong positive correlation that is evident in Figure 2 between hires and separations in both data sources. During the time period 2001:Q1 through 2014:Q2, the correlation between the LEHD hires and separations measures in Figure 2 is .973 , and the correlation for the JOLTS measures is .861. The correlation is higher in the LEHD than in the JOLTS as a consequence of differences in the two series during the 2007-09 recession. $^{24}$

One of the implications of the theory is that hires and separations move together over the business cycle. During normal times, both hires and separations equal $\mathrm{N}(1+\mathrm{F}(-\eta))$ from equation (4). During the early quarters of a recession, separations exceed hires, as seen in equations (7) and (9). During recessions, both hires and separations equal $N^{*}(1+F(-\eta))$ from equations (8) and (10), and since $\mathrm{N}^{*}<\mathrm{N}$, hires and separations are lower during recessions. The validity of each of

\footnotetext{
${ }^{23}$ This raises the interesting question of why short-duration jobs in the U.S. economy have declined so dramatically during the past 10-15 years. Ongoing work documented in Hyatt and Spletzer (2013b) has not yet revealed any simple explanations.

${ }^{24}$ During this recession, the LEHD hires and separations are both falling (with hires falling faster than separations), whereas the JOLTS hires are falling yet the JOLTS separations are initially constant before falling. When recession quarters are removed from the data, the JOLTS correlation jumps from .861 to .944 .
} 
these theoretical predictions is borne out by Figure 2. Both hires and separations are higher during normal times than during recessions.

Furthermore, as the theory predicts, separations exceed hires as the recession begins, but fall to the lower level of hires as the recession ends. Hires lead separations because adjustment first occurs for new hires and only after the labor force has shrunk do separations optimally decline. The decline in separations seems larger than that warranted by employment declines during recessions. In part, this is a result of young workers separating more than old so when the proportion of young declines, the number of separations falls by more than would be predicted were separations invariant across all age groups.

Figure 3 plots industry hiring and separation rates from the published JOLTS and LEHD data, where each industry's data point is the hires and separation rate averaged across quarters. ${ }^{25}$ The scatterplot makes clear that there are high turnover industries and low turnover industries. The leisure and hospitality industry has the highest hires and separation rates in each data source, whereas manufacturing has the lowest hires and separation rates in each data source. The scatterplot also shows that each industry has its thirteen-year average hire rate approximately equal to its thirteen-year average separation rate.

Table 1 reports the industry-specific average quarterly hires and separation rates from Figure 3 along with the industry-specific time series correlation between hires and separations from both the JOLTS and the LEHD public use data. It is evident that hires and separations are positively correlated within each industry in each data source. The positive cross-sectional

\footnotetext{
25 The public use JOLTS and LEHD data are aggregated to 12 industries: Mining, Construction, Manufacturing, Wholesale Trade, Retail Trade, Transportation and Utilities, Information, Financial Activities, Professional and Business Services, Education \& Health Services, Leisure and Hospitality Services, and Other Services. Averages are computed over the quarters in common to both data: 2001:Q1 - 2014:Q2.
} 
correlation between hires and separations is a direct prediction of the theory discussed below in section III. Because the costs and benefits of turnover vary by industry and firm and because separations equal hires in equilibrium, hires and separations move together in the cross section.

Figure 3 makes clear that industries vary in their hire and separation rates, but that these rates move together. Additionally, it is also clear from table 1 that they move together within industry over time. Six of the twelve industries in the JOLTS have a correlation greater than .8, and the other five industries have a positive correlation. In the LEHD, nine of the twelve industries have a correlation above .8, and only one the other three has a correlation less than .5 . These correlations provide evidence on the importance of industry-level churn and both are consistent with an equilibrium view of hires and separations.

The churn model implies a positive correlation between hiring and separation within industries. When an industry is experiencing high separation rates, it tends to hire more workers to replace them. Conversely, when an industry is hiring many workers, it also should be separating many workers because the matching nature of the relationship means that separation will be necessary to weed more workers out during periods of more hiring.

This implication is quite different from one that would come from the expansion/contraction view of hires and separations. If most hiring and separation reflected expansion and contraction, labor in industries that are shrinking would be taken up by industries that are growing. Industries that have high hiring rates should also have low separation rates, and vice versa. There should be a negative correlation between hiring and separation rates within industries. The expansion/contraction view is clearly not supported in the published industrylevel data as Table 1 shows. Indeed, the industry level conclusion was established years ago by 
Davis, Haltiwanger, and Schuh (1996), who showed that more than 90 percent of job reallocation is within 4-digit manufacturing industries rather than across industries.

The evidence in Table 1 and Figure 3 shows that the hire rates and the separation rates are positively correlated both across industries and over time within industries. However, the underlying microdata are needed to examine whether this correlation measures reallocation of labor across employers within industries or whether this correlation measures churn within employers. It is possible that in a given industry, some employers are primarily hiring while others are primarily laying off workers.

Employer-Level Hires, Separations, and Churn

The empirical analysis continues with an examination of churn in the LEHD microdata, which provide information on hires and separations for individual employers. These data include establishment-level measures of employment, payroll, industry, and location. ${ }^{26}$

Using the accounting framework laid out below, the microdata identify expansion hiring, contraction separations, and churn. Firms can be expanding, contracting or stable employment firms. In expanding firms, hiring exceeds separations.

Hires in expanding firms can be decomposed into growth hires and replacement hires or churn. For example, a firm that expands by three may hire seven workers and lose four workers to quits, layoffs, or retirement. The four workers hired to replace the separating workers are

\footnotetext{
${ }^{26}$ In most states, information about the part of a multi-location firm in which an individual works is maintained at a more aggregate level than establishment. Typically, this is a grouping of a firm's establishments within a state that operate in the same industry. The LEHD database includes imputed links that assign workers to specific establishments within that grouping, but the imputations generally assume that workers remain at the same location for the duration of their spell with their employer. When an employee stays with a multi-location firm but switches workplaces, that should count as a separation and hire at the establishment level, but not at the firm level. Since with-in firm moves will be understated in the LEHD data, hires and separations in this analysis should be thought of as being measured at the state/industry level for multi-location employers - a unit referred to here as "employer", rather than firm or establishment.
} 
churn and the remaining three workers are hires to grow the business. The number of replacement hires in expanding firms is equal to the number of separating workers in expanding firms.

In contracting firms, separations can be decomposed into separations that decrease the size of the firm and separations that are replaced by hired workers, which is churn. The number of replacement separations in contracting firms equals the number of workers hired in contracting firms. For example, seven workers may be separated and five may be hired. There are five separations that are replaced, that is churn, and two that reflect contraction.

In stable firms, hires exactly equal separations and hires and separations are churn.

Churn is defined as the hires and separations that offset each other for a firm. Churn is the minimum of hires and separations at the firm. Then, at the employer level

$$
\begin{array}{rlrl}
\text { Churn }=\min [\text { hires, separation }] & \\
\text { Hires for Expansion } & =\text { hires }- \text { churn } & & \text { if hires }>\text { churn } \\
& =0 & & \text { otherwise }
\end{array}
$$

Separations for Contraction $=$ separations - churn $\quad$ if separations $>0$

$$
=0 \quad \text { otherwise }
$$

\section{Evidence from the LEHD Microdata}

Figure 4 presents the seasonally adjusted time series of quarterly hires, separations, and churn from the LEHD microdata. The LEHD has 4.8 billion employee-quarter observations and 341 million firm-quarter observations. Subsets of these data are used below to perform the LEHD calculations. Table A contains the summary statistics for both employee-quarter unit of analysis variables and for employer-quarter unit of analysis variables. 
During the mid-2000s, the hires and churn rates were roughly constant at 22.8 percent and 16.6 percent, respectively. These statistics imply that 73 percent of all quarterly hiring was churn, that is, hiring associated with replacing separated workers, whereas just one-quarter of hiring is for expansion. ${ }^{27}$ In the quarters following the 2007-2009 recession, 69 percent of quarterly hiring is churn. $^{28}$

During the mid-2000s, the churn-to-separations ratio from the LEHD data is 74 percent. This number is almost identical to the churn-to-hires ratio, which is not surprising given that total hires essentially equal total separations - see Figure 4. The interpretation is that roughly threequarters of separations are replaced by a new hire during the same quarter, and just one-quarter of separations leads to a contraction of the employer.

Using the JOLTS microdata, Lazear and Spletzer (2012) report that variations in churn account for the bulk (79 percent) of total hiring change during the 2007-09 recession, which is slightly greater than the proportion that would be predicted given churn's share of total hiring. Not only is churn an important component of hiring, but it is also the main driver of cyclic hiring variation. Lazear and Spletzer argue that both churn and hiring decline during recessions because

\footnotetext{
${ }^{27}$ This finding is similar to the existing literature. Looking at quarterly statistics from the U.S. labor market, Anderson and Meyer (1994, Table 13) find that 69 percent of hiring is churn, Burgess, Lane, and Stevens (2000, Tables 1 and 2) find that roughly 70 percent of hiring is churn, Davis, Faberman, and Haltiwanger (2012) estimate that 50 percent of hiring is churn, and Lazear and Spletzer (2012) find that 65 percent of hiring is churn. Although the estimates of the churn-to-hires ratio differ across datasets and even within datasets, the literature agrees that churn is important.

${ }^{28}$ It is not possible to define churn over a period shorter than a quarter using LEHD data, as a quarter is the time unit over which the data are reported. Using this definition, offsetting hires and separations within the quarter are defined as churn. A monthly accounting would, we believe inappropriately, define these as expansion and contraction hiring. If a firm experiences separations in one month followed by an equal number of hires in the next, the quarterly definition counts that as churn, whereas a monthly definition would count it as separation for contraction followed by hires for expansion. Which is right? Hiring for expansion means that an employer continues to hire at a level that exceeds separation for a significant period of time. Hiring that exceeds separation for more than a quarter isappropriately-- counted as hiring for expansion by the LEHD quarterly definition . Similarly, separation that exceeds hiring over at least the quarter is not counted as churn by the LEHD quarterly definition, which is also appropriate
} 
separations, which during good times would have been associated with a replacement hire, are allowed to go unfilled during recessions. This is closest to the explanation of reduced hiring in this model, where workers stay out of employment because opportunities reflected in expected wages decline during recessions. The recessionary declines in hires and churn are confirmed with the LEHD microdata. During the 2007:Q4 to 2009:Q2 time period, the hire rate fell from 21.7 percent to 16.0 percent, and the churn rate fell from 15.8 percent to 11.2 percent. These statistics imply that the decline in churn during the 2007-09 recession accounts for 82 percent of the decline in hires.

Figure 4 provides evidence that employer-level churn is an important component of hiring. This is reinforced with further statistical evidence in Table 2, which presents OLS regressions of the employer-level hire rates on the employer-level separation rate. The sample used in Table 2 has over 340 million employer-quarter observations (roughly five million employers in each of the 69 quarters 1998:Q2 - 2015:Q3). The first specification in Table 2 estimates a simple onevariable regression of the establishment-level hire rate on the employer-level separation rate. The coefficient is .9395 (with a clustered and employment-weighted standard error of .0191). This estimated coefficient declines only slightly when controls are added for time (column 2) and for industry (column 3). The specification in column (4) of Table 2 speaks most directly to the importance of churn at the employer level.

Column (4) includes employer fixed effects. The estimated coefficient in this specification is .9048 , which implies that intertemporal variation in the hiring rate is similar to the separation rate for a given employer. In quarters when an employer's separation rate is high, its 
hiring rate is also high, and vice-versa. This is strong, albeit indirect evidence for the presence and importance of employer level churn.

\section{Costs and Benefits of Turnover}

If hiring is primarily for the purpose of replacement, then any factor that increases the cost of turnover on the hiring or firing side will result in less churn and both lower hiring and separation rates. Conversely, any factor that increases the benefits from a worker moving to a higher valued use will increase churn.

There are no clear measures of the cost of turnover. The time cost associated with job search is likely to be a major component of turnover costs, which implies that high wage workers face larger turnover costs than low wage ones for any given amount of time spent looking for a job. ${ }^{29}$ The empirical implication is that $\eta$ is higher and mobility lower in jobs that have higher average wages because the time cost of moving from one job to another is increasing in the wage.

The issue is more complex because there may be a correlation between $\eta$, the cost of relocating, and the value of relocating. It might be relatively cheap for low skilled workers to relocate because foregone earnings are low and the amount of time necessary to find an equivalent or better job is short. For more specialized workers, being out of work carries with it a higher cost per unit of time, but also a greater return to finding a job to which the worker is wellsuited. The difficulty is that although the costs of finding a new job may be higher for a highly skilled, heterogeneous group of workers, the gains from sorting may be larger for this group as

${ }^{29}$ Those with higher time costs will economize on search, but the cost of search still rises with the wage, even if total expenditures on search do not. 
well. It is more difficult to find a good job in the presence of heterogeneity in part because matching is more important in a heterogeneous environment.

Consequently, it is useful to examine the effect of heterogeneity on the benefit from mobility. Heterogeneity relates to the shape of the $f(\varepsilon)$ density, which provides the ingredients for determining the expected gain associated with a move from one job to another. Recall equation (1):

(1) $\quad \mathrm{V}_{\mathrm{i}}=\mathrm{V}+\varepsilon_{\mathrm{i}} \quad$ and $\quad \mathrm{V}_{\mathrm{j}}=\mathrm{V}+\varepsilon_{\mathrm{j}}$

where $\varepsilon_{\mathrm{i}}$ and $\varepsilon_{\mathrm{j}}$ are i.i.d. Also, from (2), a move occurs only when $\varepsilon_{\mathrm{i}}<-\eta$. The change in and productivity for movers is given by the expected gain from a move, which is $\mathrm{E}\left(\mathrm{V}+\varepsilon_{\mathrm{j}}-\mathrm{V}-\varepsilon_{\mathrm{i}} \mid \varepsilon_{\mathrm{i}}<\right.$ $-\eta)-\eta$, or

$$
\text { Expected gain from move }=\mathrm{E}\left(-\varepsilon_{\mathrm{i}} \mid \varepsilon_{\mathrm{i}}<-\eta\right)-\eta
$$

or equivalently,

Expected gain from move $=\frac{1}{F(-\eta)} \int_{-\infty}^{-\eta}-\varepsilon f(\varepsilon) d \varepsilon-\eta$

because $\varepsilon_{\mathrm{j}}$ is independent of $\varepsilon_{\mathrm{i}}$ and has an expectation of zero. If workers receive all the rents from the match, then the change in productivity would also be informative of the change in wages, but the goal here is to describe mobility, not wage dynamics. ${ }^{30}$

It is easy to show that under quite general conditions (for example, well-behaved symmetric distributions) that an increase in spread in the distribution also implies an increase in

\footnotetext{
${ }^{30}$ This assumption is not essential. The qualitative implications of what follows is invariant to having the rents shared in some given proportion between workers and firms.
} 
separation probabilities. To see this, consider different distributions $\mathrm{F}(\varepsilon)$ and $\mathrm{H}(\varepsilon)$. Define $\mathrm{x}^{*}$ such that $\mathrm{F}\left(\mathrm{x}^{*}\right)=\mathrm{H}\left(\mathrm{x}^{*}\right)$. Let the distributions be such that $\mathrm{h}\left(\mathrm{x}^{*}\right)<\mathrm{f}\left(\mathrm{x}^{*}\right)$ and that there is a single crossing point at $\mathrm{x}=\mathrm{A}$, so $\mathrm{f}(\mathrm{A})=\mathrm{h}(\mathrm{A})$ at $\mathrm{A}<\mathrm{x} *$. Assume further that $\eta>\mathrm{x}^{*}$. ${ }^{31}$ An example is shown in Figure 5. A distribution with higher spread is defined as one for which the height of the density function at $\mathrm{x}^{*}$ is lower and for which the value of the c.d.f.s are equal at $\mathrm{x}^{*}$. (For example, normal and uniform distributions with different variance, but the same mean satisfy the conditions.)

Separation probabilities are higher if the distribution of is $\mathrm{H}(\varepsilon)$ than if it is $\mathrm{F}(\varepsilon)$. If $-\eta<\mathrm{A}$, then it is clear that $\mathrm{H}(-\eta)>\mathrm{F}(-\eta)$, which means that separation probabilities are higher with $\mathrm{h}(\mathrm{x})$ than with $\mathrm{f}(\mathrm{x})$. It is also true more generally for $A<-\eta<\mathrm{x}^{*}$, shown as $-\eta$ ' in figure 5 , that $\mathrm{H}(-\eta)$ $>\mathrm{F}(-\eta)$. This follows because

$$
\begin{aligned}
& H(-\eta)=H\left(x^{*}\right)-\int_{-\eta}^{x^{*}} h(x) d x, \\
& F(-\eta)=F\left(x^{*}\right)-\int_{-\eta}^{x^{*}} f(x) d x, \\
& H\left(x^{*}\right)=F\left(x^{*}\right) \\
& \text { and } \\
& f(x)>h(x) \forall A<x<x^{*}
\end{aligned}
$$

Consequently, separations rise when the spread in the underlying distribution increases.

To the extent that the standard deviation of wages proxies spread as defined here, the implication is that churn should be increasing in the standard deviations of wages. As long as some of the match-specific rent is shared with the workers, it is reasonable to assume that the wage distribution is increasing in the spread of the distribution of the match-specific component,

\footnotetext{
${ }^{31}$ This is natural if $\mathrm{x}^{*}=0$, but this is not necessary.
} 
$\varepsilon .{ }^{32}$ It is certainly, true, however, that other components might also affect the wage spread.

Underlying observed worker heterogeneity, independent of the match component, is likely to be reflected in wage spread as well. To deal with this, worker groups are defined narrowly so as to remove observable and measurable sources of heterogeneity.

First the analysis is done using the actual log earnings distribution, with corrections for worker heterogeneity. The theory has assumed for simplicity that all individuals are homogeneous. But at the empirical level, it is necessary to drop this simplifying assumption. For example, the wage distribution of teenagers is not the same as the wage distribution of college educated middle-aged persons. To account for these differences, assume that an individual's labor market in a given quarter can be defined by the gender, age, education, industry, and state of that individual. This stratification generates 17,632 different cells each quarter, and each cell is allowed to have its own wage distribution. The mean and standard deviation of the wage distribution for a given cell are measured in each quarter using log full-quarter earnings of all individuals with the same gender, age group, education, industry, and state. ${ }^{33}$

The two interpretations of the model influence the empirical work. The model can be viewed from the perspective of the individual - a worker separates when the alternative wage, net of moving costs, is higher than the wage that is received at the current employer. This occurs

\footnotetext{
${ }^{32}$ Without a specific model of rent sharing, it is impossible to say how much of the observed distribution of wages reflects the underlying distribution. The assumption here is that the standard deviation of the observed distribution is highly correlated with the standard deviation of the true productivity distribution across markets.

${ }_{33}$ There are 2 genders, 4 age groups, 4 education categories , 19 industries, and 29states. Thus potentially 17,632 earnings distributions are created for every quarter in the dataset (1998:Q3 - 2015:Q2) though some are not populated. Some technical details warrant mentioning. First, the quarterly earnings microdata have been Winsorized at $99 \%$ of the state-year-quarter distribution to control for outliers that do affect the mean and the standard deviation. Second, all earnings measures are in real terms (2011:Q4=100) and in natural logs. And third, only "full quarter earnings" are used in the calculation, where full quarter earnings are the quarterly earnings for an individual who works for the current employer in both the previous and the following quarter. The LEHD does not have measures of hours or weeks worked, and this full quarter earnings restriction assumes that the individual works for the employer all 13 weeks of the quarter. The education variable is imputed for the majority of individuals.
} 
when $\varepsilon_{\mathrm{i}}<-\eta$. Workers are defined by their labor markets, which is the gender-age-educationindustry-state specific cell. The alternative interpretation is at the employer level. Employers separate workers and hire a new worker to replace the separated one when the expected value of the new worker, net of hiring costs, exceeds the productivity of the incumbent. This occurs when $\varepsilon_{\mathrm{i}}<-\eta$, which is the same condition. The efficient separation framework does not require nor speak to the identity of the separation decision maker. Consequently, the empirical analysis is done at both the worker and employer levels. Each is informative and the results obtained are reinforcing.

The worker level regressions take a labor market, i.e., a cell, as the unit of analysis. The theory predicts that cells with a low mean wage and a high standard deviation of wages should experience the highest turnover because the representative worker in that cell has low costs of search and higher expected value from moving.

The employer level regressions speak to the issue of churn, which is most sensibly defined in the context of the employer. ${ }^{34}$ A worker may be hired or separated, but to know whether that hire or separation reflected expansion, contraction or churn, it is necessary to know what happened to the number of hires and separations at the specific employer that hired the worker from which the worker separated. If hiring and separation is primarily for replacement, as demonstrated above, then understanding churn is central. The employer-based regressions determine how churn (in addition to hiring and separation) varies with the costs and benefits of efficient sorting of workers.

\footnotetext{
${ }^{34}$ One could think of an industry as a "firm," which hires for the purpose of expansion, contraction or replacement, but the industry is not the decision making unit. Churn is best defined in the context of the employer or even small units like a department within a firm. Data on smaller units are difficult to obtain.
} 
It is also important to point out that the empirical implications neither require nor test efficient matching. Although the model is stated in terms of churn reflecting an efficient allocation of labor, churn could just as well be a result of rent seeking and the implications would remain. For example, suppose that a worker's productivity were the same at two employers $i$ and $\mathrm{j}$, but that employer $\mathrm{j}$ used a rent-splitting algorithm that favored workers more than did employer i. Were a worker to receive an offer from employer $\mathrm{j}$, he would leave employer $\mathrm{i}$, vacating a position and leaving an open slot. Churn would result. Furthermore, the likelihood of moving depends on the cost of moving, again related to the wage level, and on the value of moving, also related to the variance in wages across employers.

\section{Worker-based Job Separation Regressions}

The mean and the standard deviation of the individual's relevant log earnings distribution are the key explanatory variables in the job separation regressions. The prediction of the theory is that job separation should be negatively related to the log earnings level and positively related to the standard deviation. The unit of analysis for the worker-based regressions is the quarterlyworker-type cell.

Table 3 reports the results from job separation regressions. Workers younger than 25 or older than 64 are excluded from the sample. There are about 1.25 million observations in this quarter-worker-type data set. ${ }^{35}$ All specifications include year and quarter. Observations are weighted by cell employment and standard errors are clustered at the cell level.

\footnotetext{
35 Restricting to age 25-64 and full-quarter jobs drops the sample of individual-quarter observations to 3.27 billion. There are potentially 1,269,504 labor markets, or cells, in this sample: 2 genders, 4 age groups, 4 education categories, 19 industries, 29 states, and 72 quarters of "full quarter" data (1998:Q3 - 2015:Q2). The average cell has 2135 individuals.
} 
The results in Table 3 conform to the theoretical predictions. There is a strong negative relation of job separation to log earnings. The higher is the time cost of separation, the lower is the likelihood of turnover. There is a strong positive relation of job separation to the variance in log earnings, reflecting higher potential benefit from a move. The regression results support the view, expressed by the theory, that separations are related in the expected direction to the costs of and benefits from mobility. As the wage rises, the cost of turnover rises and separation becomes less common. Additionally, and less easily explained by other theories, is that as the standard deviation of log earnings rises, the benefit from turnover rises and turnover is more common.

The estimated effects are large. The mean of the full quarter separation rate is $.118 .^{36}$ Using the column (3) estimates, a one standard deviation increase in the average market log earnings reduces expected turnover by $.020,(.0379 \times .529=.020)$, which is about $17 \%$ of the average turnover rate. A one standard deviation increase in the standard deviation of the $\log$ earnings of the cell in which the worker is situated increases turnover by $.0046,(.0217 \mathrm{x}$ $.213=.0046)$, which is about $4 \%$ of the average turnover rate.

\section{Employer Turnover Regressions}

Churn is a concept that makes sense only at the employer level, where workers are hired to replace separating workers. ${ }^{37}$ Because of the stylized model structure, there is no explicit need to

\footnotetext{
${ }^{36}$ See appendix Table A for sample summary statistics.

${ }^{37}$ Actually needed is that the unit that hires/separates is an ongoing concern, which continues beyond the single worker's employment horizon. The entity could be a firm, an establishment or even a department. Required is that the entity can hire to replace departing workers. Churn cannot be defined for a worker because a worker cannot hire and replace himself and whether his hire is for expansion or churn cannot be determined without examining the hiring entity.
} 
consider ex ante worker heterogeneity in the theory. In reality, nothing requires that the employer hire only one type of worker.

For empirical implementation, it is necessary to define the employer's "representative" worker in order to obtain predictions for each firm's churn. For each of the employer's workers, there is a corresponding worker-type cell from which the worker was drawn. The cell to which the worker belongs defines the worker's "type" which determines the mean and standard deviation of log earnings assigned to that worker. Then, simply by averaging over all workers at a given employer, it is possible to define the firm's "typical" worker's mean and standard deviation of log earnings. The employer-level regressions are estimated from a sample of 280 million employer-quarter observations, which is approximately 4 million employers each quarter. Only individuals aged 25-64 were used when calculating the employer-level variables. Results are presented in Table 4, using hires, separations, and churn as the dependent variable.

The results are all consistent with the theoretical predictions and with those obtained in Table 3. Employers that have a typical worker with a higher mean log earnings have lower separation rates, hiring rates, and churn rates. As expected, higher turnover costs result in less turnover. Additionally, employers with workers who come from labor markets with higher log earnings variation have greater separation, hiring, and churn rates. This finding is also consistent with the model. To the extent that log earnings variation in the market measures, or is at least related to, the variation in employer-worker match effects, churn should be more common at employers where match effects are more important.

The results from the employer-level regressions largely mimic the results from the celllevel regressions. Also of note in Table 4 is that the regression coefficients in the hiring rate 
regression are very similar to those in the separation rate regression. This is not surprising since hiring and separation rates are so highly correlated, even at the employer level. The effect of costs and benefits of turnover is significant and economically meaningful. A one standard deviation increase in the typical mean log earnings of an employer's workers results in about a 1.9 percentage point decrease in churn, which is about one-fourth of the overall churn rate. Additionally, a one-standard deviation increase in the typical standard deviation of mean log earnings of an employer's workers results in a .27 percentage point increase in churn, which is about one-twentieth of the overall churn rate. The latter effect reflects the importance of heterogeneity in worker-firm productivity and addresses the value of efficient sorting. The former effect is directly related to the cost of transitioning from one job to another, which is higher for high wage workers. Consequently, employers with higher wage workers engage in less churn.

Firm fixed effects are important. Just as there are high and low turnover industries, so too are there high and low turnover firms. In Table 4, the R-squared in the churn regression rises from 0.035 to 0.448 when firm fixed effects are included. Furthermore, the standard deviation of firm fixed effects is 0.255 , which is about $2 / 3$ of the overall standard deviation across all firms and periods in churn rates.

\section{Employment and the Business Cycle}

The model predicts that young workers are the ones who bear the brunt of reductions in employment during recessions. To test this, employment entry rates are created from the LEHD microdata. The employment entry rate in quarter $t$ is defined as the percent of individuals who do 
not work for any private sector firm for four consecutive quarters, and then begin work in quarter t. $^{38}$

The seasonally adjusted time series of employment entry rates are presented in Figure 6. The employment entry rates for young persons aged 16-24 appear to be more cyclically sensitive than those for older groups. In the mid-2000s, the percentage of young persons (aged 16-24) entering employment in any given quarter averages 6.5 percent. This falls to 4.4 percent at the end of the 2007-09 recession. This absolute decline of 2.1 percentage points is greater than for any other age group. The relative difference remains, albeit less pronounced, when the declines are expressed proportionately, i.e., relative to the group mean rates.

\section{Conclusion}

Most hiring and separations reflect churn. Using the LEHD microdata, it is estimated that about $70 \%$ of quarterly hiring is for the purpose of replacement. Hiring for expansion and separation for contraction occur in the labor market, but most hiring and separation reflects steady-state mobility, not the growth or decline of businesses. Thus, to understand hiring and separation, it is necessary to explain churn. The framework in this paper is one of efficient separations. Workers separate and move to better jobs when the benefit from doing so is positive and firms hire to replace separated workers and lay off workers when the expected productivity of a new worker, net of hiring costs, exceeds that of the incumbent.

\footnotetext{
${ }^{38}$ Restricting to four quarters of non-employment within the state, rather than across states, makes the computation tractable. Population data for the denominator of each rate are national data from www.bls.gov/cps, multiplied by .65 to reflect their use in a 30 state sample.
} 
The theory presented links hiring to separation in a direct way. The model predicts that hiring and separation move together, both over time and across firms. In this crucial way, relative changes in demand as an explanation of hiring and separation is de-emphasized.

If churn is the bulk of hiring and separation, then hiring and separation are mirror images of one another and are linked in equilibrium. Consequently, hiring and separation should be positively correlated over time in aggregate, within industries, and even within firms. The data clearly show that hiring and separations move together in the aggregate and within industries in both JOLTS and LEHD data. The LEHD data also reveal that this phenomenon holds strongly at the employer level. Employers are hiring and separating workers at the same time and replacement hiring is the bulk of hiring at the employer level.

The model also provides specific predictions with respect to business cycle hiring and separation patters. When a recession takes hold, hires fall first or by more than separations. Separations decline later to match hiring. This prediction is borne out by both the JOLTS and LEHD data.

The mean and standard deviation of log earnings within a labor market cell (defined by gender, age, education, industry, and location) are used as empirical proxies for the cost and benefits of turnover. The results show that as predicted, higher turnover costs are associated with lower hire, separation and churn rates, whereas higher benefits of turnover are associated with larger hire, separation and churn rates.

The strong positive correlation between hiring and separation rates is consistent with the view that separation and hiring reflect the same economic factors. The churn view of the labor 
market seems to be powerful in explaining cross-section and time series variations in both hiring and separation. 


\section{References}

Abowd, J., Corbel, P., \& Kramarz, F. 1999. "The Entry and Exit of Workers and the Growth of Employment." Review of Economics and Statistics 81(2), 170-187

Albaek, K., \& Sorensen, B. E. 1998. "Worker Flows and Job Flows in Danish Manufacturing, 1980-91.” Economic Journal 108(451), 1750-71.

Anderson, Patricia M. and Bruce Meyer. 1994. "The Extent and Consequences of Job Turnover." Brookings Papers on Economic Activity.

Bentolila, Samuel \& Bertola, Giuseppe. 1990. "Firing Costs and Labour Demand: How Bad Is Eurosclerosis?" Review of Economic Studies, 57(3), 381-402.

Burgess, S., Lane, J., Stevens, D. 2000. “Job flows, worker flows and churning." Journal of Labor Economics 18(3), 473-502.

Burgess, S., Lane, J., Stevens, D. 2001. “Churning dynamics: an analysis of hires and separations at the employer level." Labour Economics 8(1), 1- 14.

Davis, Steven J., R. Jason Faberman and John Haltiwanger. 2006. “The Flow Approach to Labor Markets: New Data Sources and Micro-Macro Links.” Journal of Economic Perspectives, 20(3), 3-16.

Davis, Steven J., R. Jason Faberman, and John C. Haltiwanger. 2012. "Labor Market Flows in the Cross Section and over Time." Journal of Monetary Economics 59(1): 1-18.

Davis, Steven J. and John Haltiwanger. 1992. “Gross Job Creation, Gross Job Destruction, and Employment Reallocation.” Quarterly Journal of Economics 107(3), 819-863.

Davis, S.J., Haltiwanger, J.C. and Schuh, S., 1998. Job Creation and Destruction. MIT Press Books.

Faberman, Jason and Éva Nagypál. 2008. “Quits, Worker Recruitment, and Firm Growth: Theory and Evidence.” Federal Reserve Bank of Philadelphia Working Paper No. 08-13.

Fujita, S. and Moscarini, G., 2013. "Recall and Unemployment. National Bureau of Economic Research Working Paper No. W19640.

Hall, Robert. 2011. “The Long Slump.” American Economic Review, 101(2) 431-469.

Hamermesh, D.S., Hassink, W. H. J., Van Ours, J.C. 1996. "Job Turnover and Labor Turnover: A taxonomy of Employment Dynamics." Annales d.Economie et de Statistique 41-42, 21 39. 
Hyatt, Henry R. and James R. Spletzer. 2013a. "The Recent Decline in Employment Dynamics." IZA Journal of Labor Economics, Vol. 2, No. 5, 2013, pp. 1-21.

Hyatt, Henry R. and James R. Spletzer. 2013b. "The Recent Decline in Short Duration Jobs." Unpublished paper, U.S. Census Bureau.

Jovanovic, Boyan. 1979. "Job Matching and the Theory of Turnover." Journal of Political Economy 87(5), 972-990.

Lazear, Edward P. 1990. “Job security provisions and employment." Quarterly Journal of Economics 105(3), 699-726.

Lazear, Edward P. and Kathryn L. Shaw (eds). 2009. The Structure of Wages: An International Comparison. Chicago: University of Chicago Press.

Lazear, Edward P. and James R. Spletzer. 2012. "Hiring, Churn, and the Business Cycle." American Economic Review Papers and Proceedings 101(3) 575-579.

McLaughlin, Kenneth. 1991. “A Theory of Quits and Layoffs with Efficient Turnover.” Journal of Political Economy 99(1) 1-29.

Moulton, Brent R. 1990. "An Illustration of a Pitfall in Estimating the Effects of Aggregate Variables on Micro Units." The Review of Economics and Statistics 72(2) 334-338.

Picot, Garnett, Andrew Heisz and Alice Nakamura. 2000. "Were the 1990s Labour Markets Really Different?" Policy Options, July-August. 
Figure 1: Hires and Separations During a Recession Equations (7) - (10) of the Model

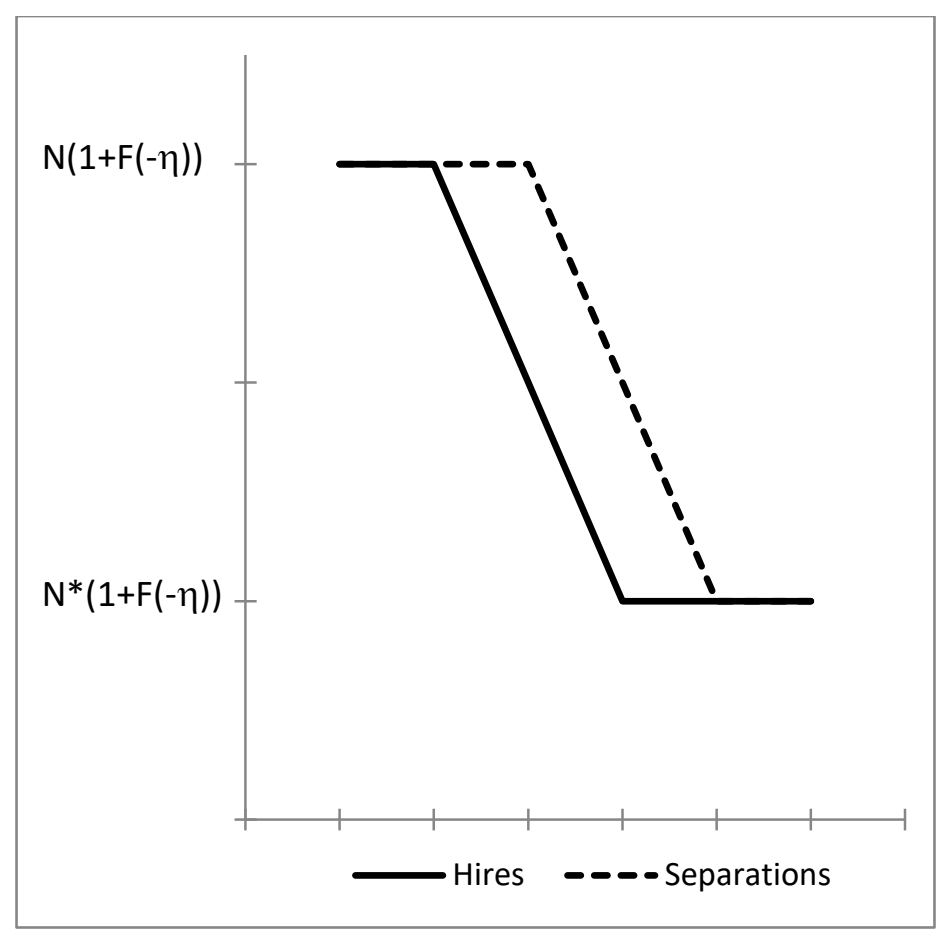


Figure 2: Quarterly Hire and Separation Rates

LEHD Data,1998Q2-2014:Q2 (29 States)

JOLTS Data, 2001Q1-2014Q3 (National)

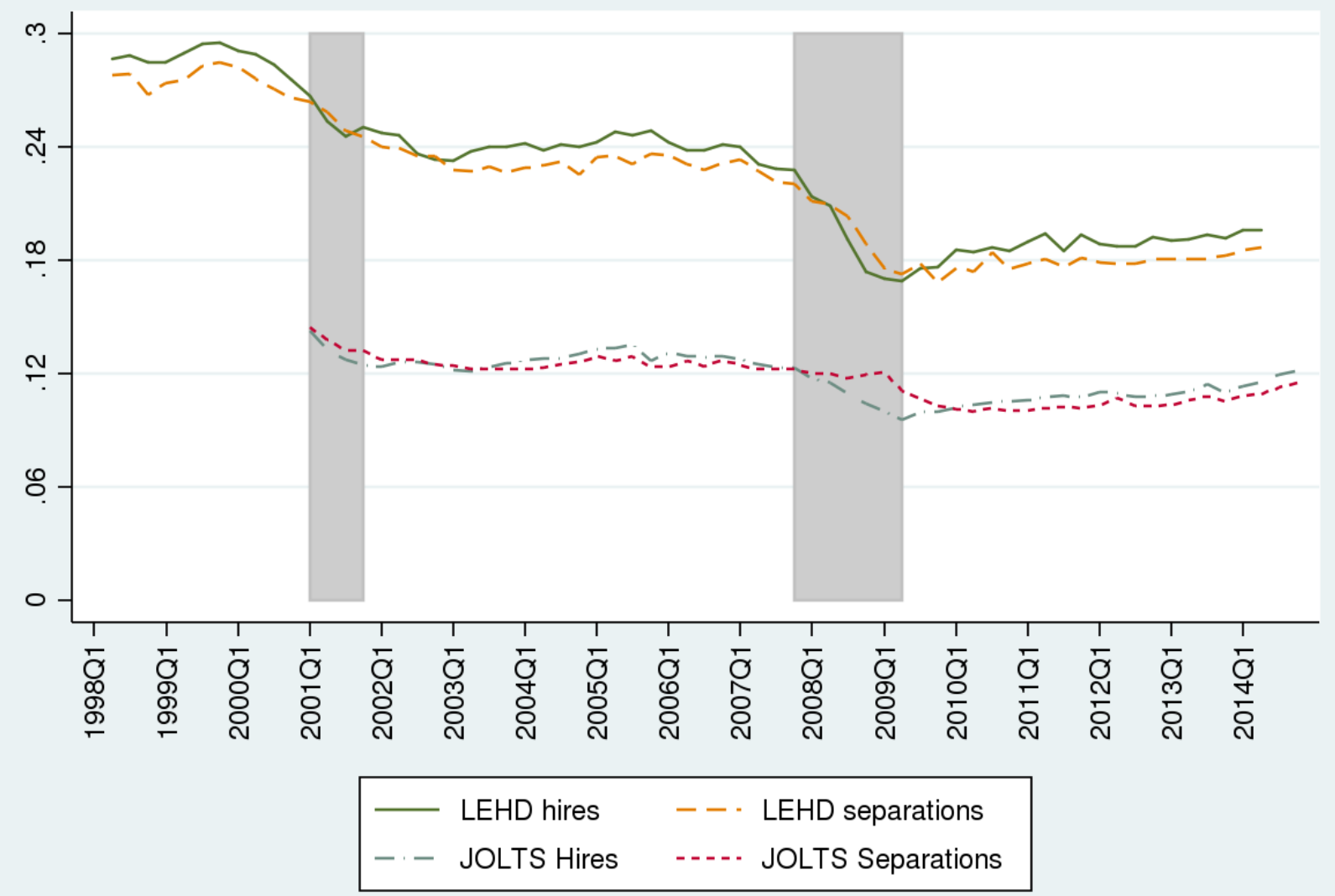

Series are for private sector, and have been seasonally adjusted. 


\section{Figure 3: Quarterly Hires and Separation rates, by Industry JOLTS Data (left panel), Averages 2001:Q1 - 2014:Q3 \\ LEHD Data (right panel), Averages 2001:Q1 - 2014:Q3}
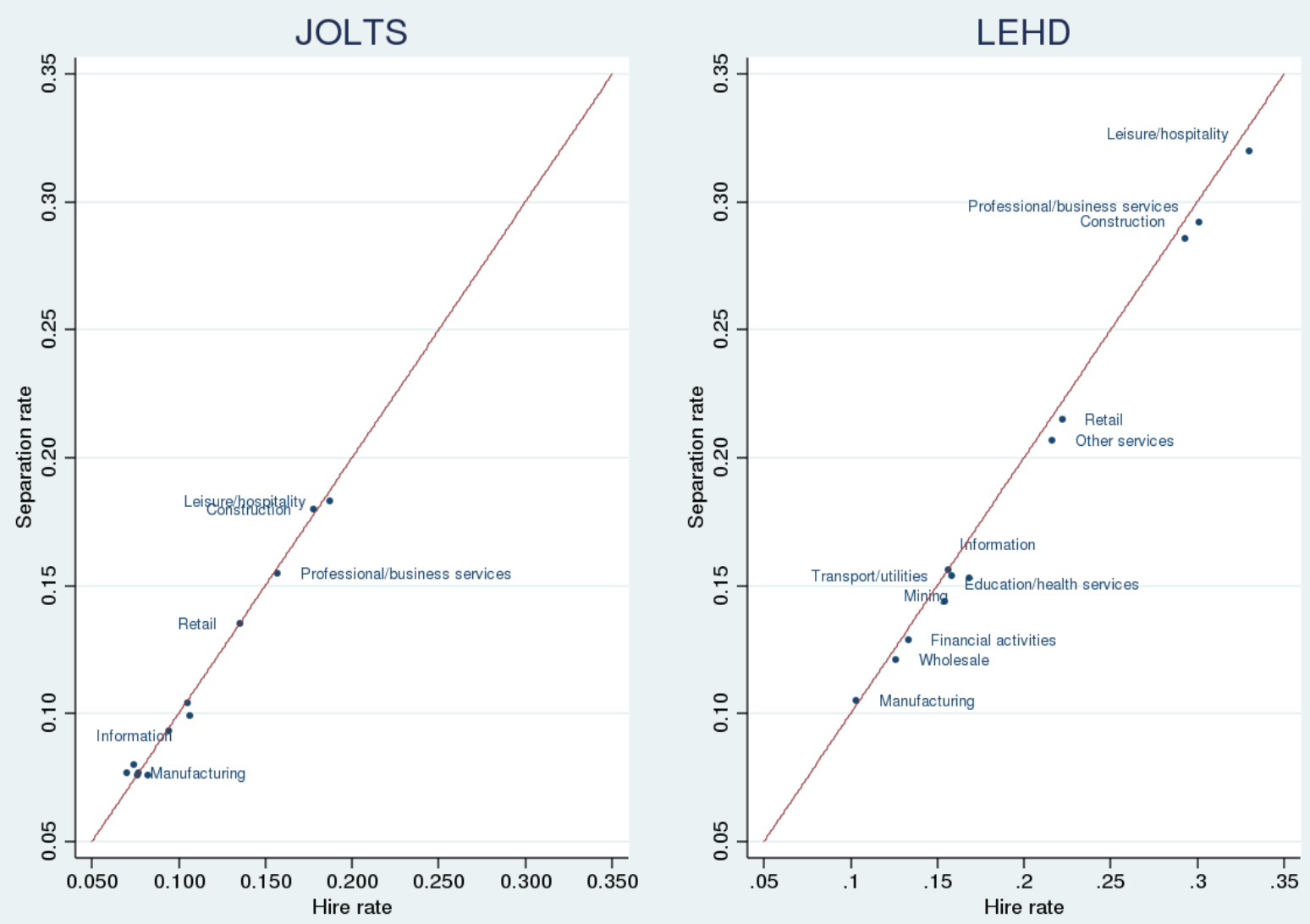

Source: Authors' calculations from Job Openings and Labor Turnover Survey (JOLTS) and LEHD Quarterly Workforce Indicators (QWI) statistics. JOLTS monthly statistics converted to a quarterly frequency.

LEHD statistics are employment-weighted averages of QWI statistics for 29 states.

Both sets of statistics are for the private sector and have been seasonally adjusted by the authors. 
Table A: Sample summary statistics

\begin{tabular}{|c|c|c|c|c|}
\hline \multirow[b]{3}{*}{ Rates (employer-quarter based) } & \multicolumn{4}{|c|}{ Samples } \\
\hline & \multicolumn{2}{|c|}{ All jobs } & \multicolumn{2}{|c|}{ Full-quarter jobs } \\
\hline & Mean & Std Dev & Mean & Std Dev \\
\hline Hires & 0.238 & 1.304 & 0.103 & 0.066 \\
\hline Separations & 0.254 & 1.317 & 0.118 & 0.124 \\
\hline Churn & 0.165 & 1.267 & 0.091 & 0.043 \\
\hline \multicolumn{5}{|l|}{$\begin{array}{l}\text { Worker characteristics (employee-quarter } \\
\text { based) }\end{array}$} \\
\hline Log full-quarter earnings & & & 8.80 & 0.739 \\
\hline Cell mean log full-quarter earnings & & & 8.80 & 0.529 \\
\hline Cell standard deviation of log full-quarter earnings & & & 0.825 & 0.213 \\
\hline Female & & & 0.47 & \\
\hline Age & & & 42.5 & 10.1 \\
\hline \multicolumn{5}{|l|}{ Education categories } \\
\hline Less than HS & & & 0.135 & \\
\hline HS graduate & & & 0.273 & \\
\hline Some college & & & 0.317 & \\
\hline College graduate & & & 0.275 & \\
\hline Years of education & & & 13.5 & 2.02 \\
\hline \multicolumn{5}{|l|}{ Sample sizes } \\
\hline Number of job/quarters included & \multicolumn{2}{|c|}{$4.79 \mathrm{~B}$} & \multicolumn{2}{|c|}{$3.27 \mathrm{~B}$} \\
\hline Number of employer/quarters included & \multirow{2}{*}{\multicolumn{2}{|c|}{$340.9 \mathrm{M}$}} & \multirow{2}{*}{\multicolumn{2}{|c|}{$\begin{array}{c}280.2 \mathrm{M} \\
1,249,622\end{array}$}} \\
\hline Number of cell/quarters & & & & \\
\hline
\end{tabular}

Notes: All jobs sample includes all private-sector job/quarters at employers with at least one employee at either the beginning or end of the quarter in our sample of 29 states, over the period 1998q2-2015q2. Full-quarter jobs sample includes the subset of full-quarter jobs held by those aged 25-64. A job is classified as full-quarter in quarter $t$ if the individual has earnings with that employer in quarters $t-1 / t / t+1$. For some analyses, the full-quarter sample of jobs is classified into cells based on quarter, state, industry sector, 10-year age groups, education categories, and gender. All statistics are employment weighted. 
Table 1: Quarterly Hires and Separation Rates, by Industry

\begin{tabular}{lcccccc}
\hline & \multicolumn{2}{c}{ JOLTS 2001Q1-2014Q2 } & \multicolumn{2}{c}{ QWI 2001Q1-2014Q2 } \\
Average & $\begin{array}{c}\text { Average } \\
\text { separation } \\
\text { rire rate }\end{array}$ & $\begin{array}{c}\text { Time } \\
\text { series } \\
\text { correlation }\end{array}$ & $\begin{array}{c}\text { Average } \\
\text { hire rate }\end{array}$ & $\begin{array}{c}\text { Average } \\
\text { separation } \\
\text { rate }\end{array}$ & $\begin{array}{c}\text { Time } \\
\text { series } \\
\text { correlation }\end{array}$ \\
\hline Mining and logging & 0.106 & 0.099 & 0.029 & 0.168 & 0.153 & 0.476 \\
Construction & 0.178 & 0.180 & 0.583 & 0.293 & 0.286 & 0.869 \\
Manufacturing & 0.070 & 0.077 & 0.451 & 0.103 & 0.105 & 0.724 \\
Wholesale trade & 0.076 & 0.076 & 0.761 & 0.126 & 0.121 & 0.918 \\
Retail trade & 0.135 & 0.135 & 0.931 & 0.222 & 0.215 & 0.982 \\
Transport, warehousing, utilities & 0.094 & 0.093 & 0.670 & 0.158 & 0.154 & 0.894 \\
Information & 0.074 & 0.080 & 0.780 & 0.156 & 0.156 & 0.713 \\
Financial activities & 0.077 & 0.077 & 0.859 & 0.133 & 0.129 & 0.933 \\
Professional and business services & 0.157 & 0.155 & 0.853 & 0.301 & 0.292 & 0.982 \\
Education and health services & 0.082 & 0.076 & 0.954 & 0.154 & 0.144 & 0.987 \\
Leisure and hospitality & 0.187 & 0.183 & 0.977 & 0.330 & 0.320 & 0.992 \\
Other services & 0.105 & 0.104 & 0.891 & 0.216 & 0.207 & 0.989 \\
\hline Private, non-farm & 0.118 & 0.117 & 0.861 & 0.216 & 0.209 & 0.973 \\
\hline
\end{tabular}

Source: Authors' calculations based on Bureau of Labor Statistics national JOLTS statistics and Census Bureau QWI statistics for 29 states. JOLTS monthly data were converted to a quarterly frequency. All data are for the private sector and were seasonally adjusted by the authors. 
(1)

Separation rate

Intercept
(2)

(3)

(4)

$\begin{array}{cccc}0.9395 * * * & 0.9593 * * * & 0.9390 * * * & 0.9048 * * * \\ (0.0191) & (0.0131) & (0.0194) & (0.0250) \\ & & & \\ 0.0001 & -0.0050 & 0.0002 & 0.0089 \\ (0.0048) & (0.0033) & (0.0049) & (0.0064)\end{array}$

Fixed effects:

Year* quarter

Industry (2-digit NAICS sector)

Employer

No

Yes

No

No

No

No

Yes

No

No

No

No

Yes

R-squared

0.9000

0.9177

0.9000

0.9031

Source: LEHD microdata for private sector in 29 states. Standard errors in parentheses. Dependent variable is the ratio of hires in current quarter over the average of the count of employees at the beginning and the end of the quarter. All regressions are employment weighted. Sample size is $340.9 \mathrm{M}$ employer-quarter observations. Standard errors are clustered at the employer level. 


\section{Figure 4: Quarterly Hires, Separations, and Churn Rates}

LEHD Data, 1998:Q2 - 2015:Q1

LEHD microdata for 29 states, private sector.

Each series is seasonally adjusted.

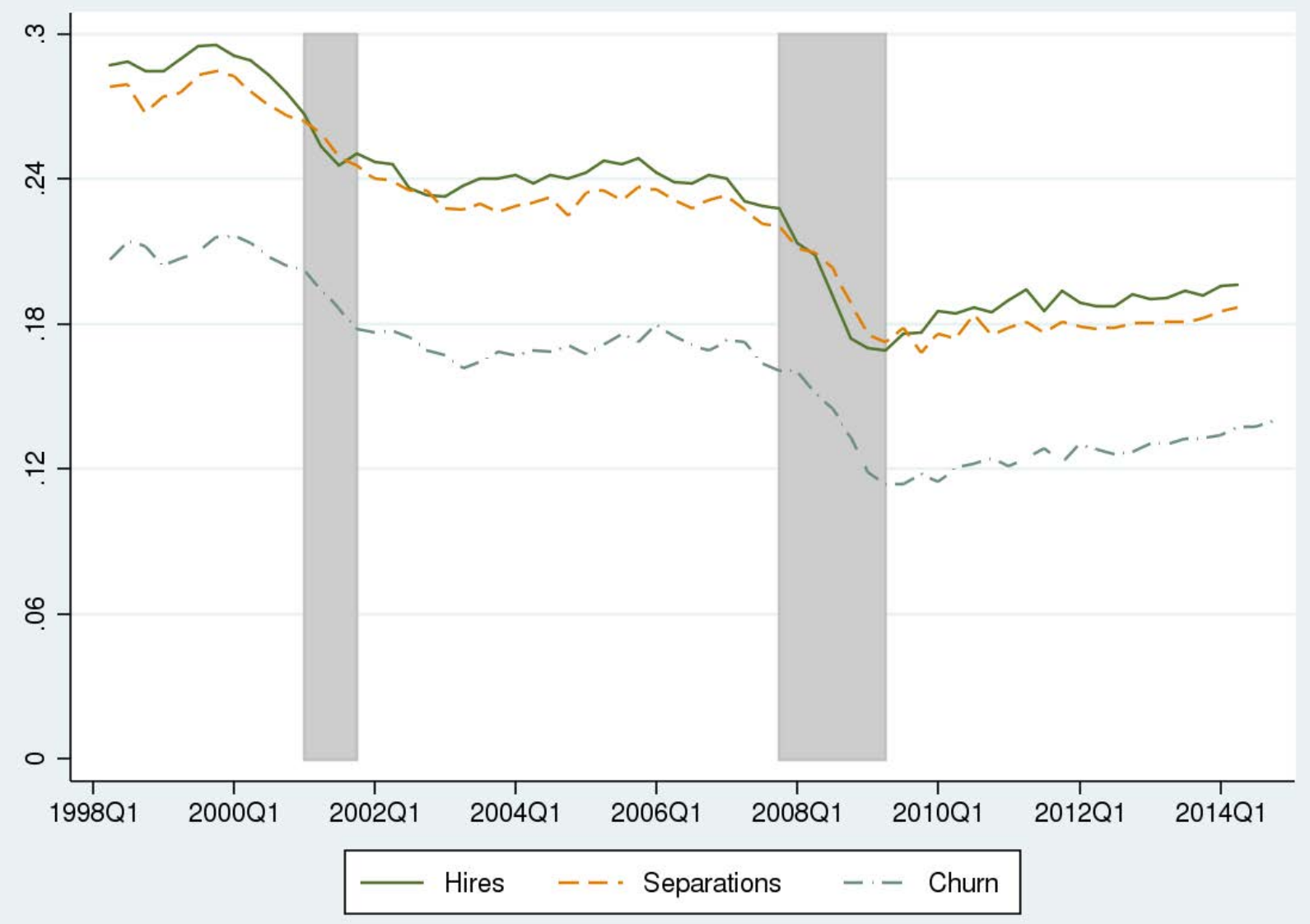

Source: Churn rates based on authors' calculations from private-sector LEHD microdata for 29 states. Hire and separation rates are based on QWI statistics. 
Figure 5: Two Hypothetical Wage Densities

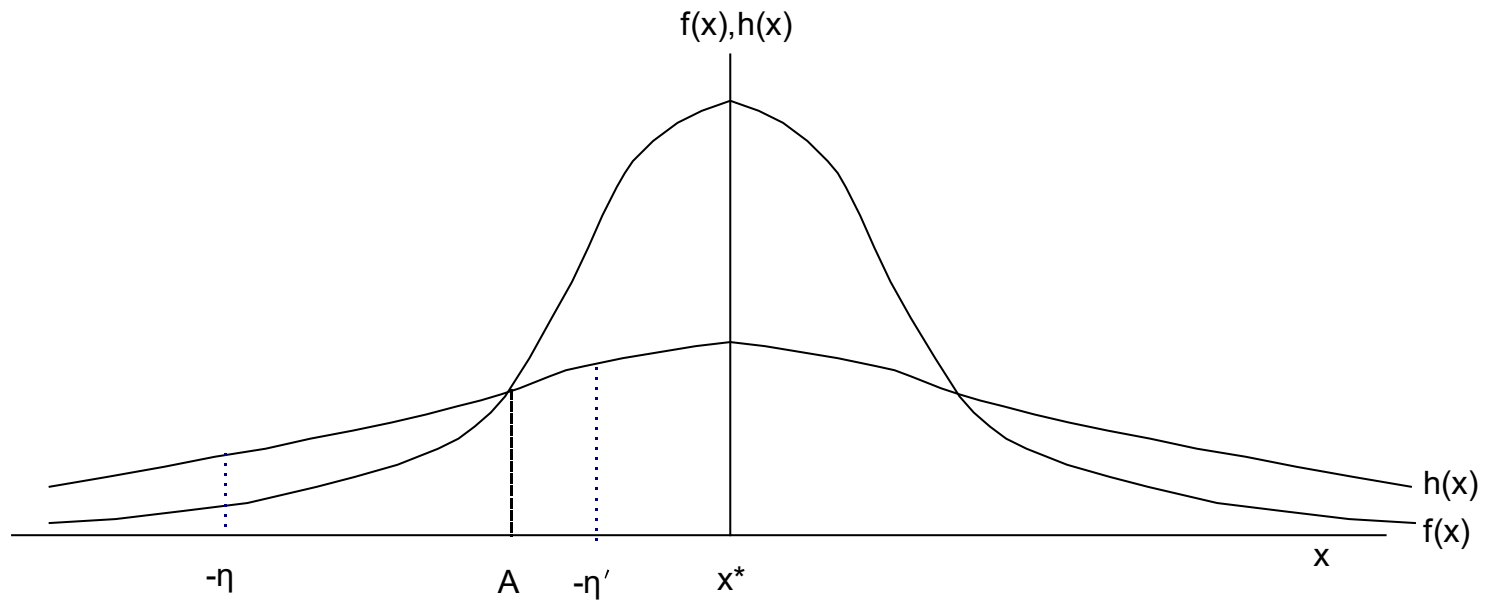


Table 3: Job Separation Regressions, LEHD Full-quarter Jobs (Worker Cell)

\begin{tabular}{|c|c|c|c|}
\hline & (1) & (2) & (3) \\
\hline Mean log earnings in cell & $\begin{array}{c}-0.0370^{* * * *} \\
(0.0009)\end{array}$ & $\begin{array}{c}-0.0352 * * * \\
(0.0010)\end{array}$ & $\begin{array}{c}-0.0379 * * * \\
(0.0012)\end{array}$ \\
\hline Standard deviation of log earnings in cell & & $\begin{array}{c}0.0123 * * * \\
(0.0023)\end{array}$ & $\begin{array}{c}0.0217 * * * \\
(0.0033)\end{array}$ \\
\hline Female & & & $\begin{array}{c}-0.0167 * * * \\
(0.0009)\end{array}$ \\
\hline Age $35-44$ & & & $\begin{array}{c}-0.0237 * * * \\
(0.0012)\end{array}$ \\
\hline Age $45-54$ & & & $\begin{array}{c}-0.0369 * * * \\
(0.0011)\end{array}$ \\
\hline Age 55-64 & & & $\begin{array}{c}-0.0417 * * * \\
(0.0011)\end{array}$ \\
\hline Less than high school education & & & $\begin{array}{c}-0.0229 * * * \\
(0.0021)\end{array}$ \\
\hline High school graduate & & & $\begin{array}{c}-0.0310 * * * \\
(0.0019)\end{array}$ \\
\hline Some college & & & $\begin{array}{c}-0.0297 * * * \\
(0.0019)\end{array}$ \\
\hline College graduate & & & $\begin{array}{c}-0.0244 * * * \\
(0.0021)\end{array}$ \\
\hline Intercept & $\begin{array}{c}0.4429 * * * \\
(0.0083)\end{array}$ & $\begin{array}{c}0.4174 * * * \\
(0.0094)\end{array}$ & $\begin{array}{c}0.4923 * * * \\
(0.0121)\end{array}$ \\
\hline R-squared & 0.8977 & 0.8981 & 0.9195 \\
\hline
\end{tabular}


Source: LEHD microdata for private sector in 29 states 1998Q3-2015Q2. Unit of observation is a state/quarter industry/age/gender/education cell. All regressions are weighted by cell employment and include year/quarter dummies. Sample size is $1.2 \mathrm{M}$ cell quarter observations. Dependent variable is the cell share of individuals leaving a full-quarter job in the next quarter. Standard errors (in parentheses) are clustered at the cell level. Omitted categories are men, ages 25-34, and missing value for education. 
Table 4: Hire, Separation, and Churn Rate Regressions, LEHD Full-Quarter Jobs (Employer)

\begin{tabular}{|c|c|c|c|c|c|c|}
\hline & \multicolumn{2}{|c|}{ Separation Rate } & \multicolumn{2}{|c|}{ Hire Rate } & \multicolumn{2}{|c|}{ Churn Rate } \\
\hline & (1) & (2) & (3) & (4) & (5) & (6) \\
\hline $\begin{array}{l}\text { Mean log earnings } \\
\text { in cell }\end{array}$ & $\begin{array}{c}-0.0460 * * * \\
(0.0007)\end{array}$ & $\begin{array}{c}-0.0442 * * * \\
(0.0009)\end{array}$ & $\begin{array}{c}-0.0473 * * * \\
(0.0007)\end{array}$ & $\begin{array}{c}-0.0448 * * * \\
(0.0009)\end{array}$ & $\begin{array}{c}-0.0351 * * * \\
(0.0004)\end{array}$ & $\begin{array}{c}-0.0322 * * * \\
(0.0006)\end{array}$ \\
\hline $\begin{array}{l}\text { Standard deviation } \\
\text { of log earnings in } \\
\text { cell }\end{array}$ & & $\begin{array}{l}.0079 * * * \\
(0.0028)\end{array}$ & & $\begin{array}{l}.0107 * * * \\
(0.0032)\end{array}$ & & $\begin{array}{c}0.0129 * * * \\
(0.0025)\end{array}$ \\
\hline Intercept & $\begin{array}{c}0.5224 * * * \\
(0.0060)\end{array}$ & $\begin{array}{c}0.5001 * * * \\
(0.0098)\end{array}$ & $\begin{array}{c}0.5185 * * * \\
(0.0060)\end{array}$ & $\begin{array}{c}0.4882 * * * \\
(0.0103)\end{array}$ & $\begin{array}{c}0.3616^{* * *} \\
(0.0032)\end{array}$ & $\begin{array}{c}0.3249 * * * \\
(0.0069)\end{array}$ \\
\hline R-squared & 0.3056 & 0.3057 & 0.0271 & 0.0272 & 0.0344 & 0.0350 \\
\hline
\end{tabular}

Source: LEHD microdata for private sector in 29 states, 1998Q3-2015Q2. Unit of observation is an employer/quarter. Mean and standard deviation of wage for a typical worker are based on a worker-weighted average of log full-quarter earnings in cells as defined in Table 3. Dependent variables are rates for full-quarter employees. All regressions are weighted by cell employment and include year/quarter dummies. Sample size is 280.2M employer/quarter observations. Standard errors (in parentheses) are clustered at the employer level. 
Figure 6: Quarterly Employment Entry Rates, by Age

LEHD Data, 1998:Q2 - 2010:Q4

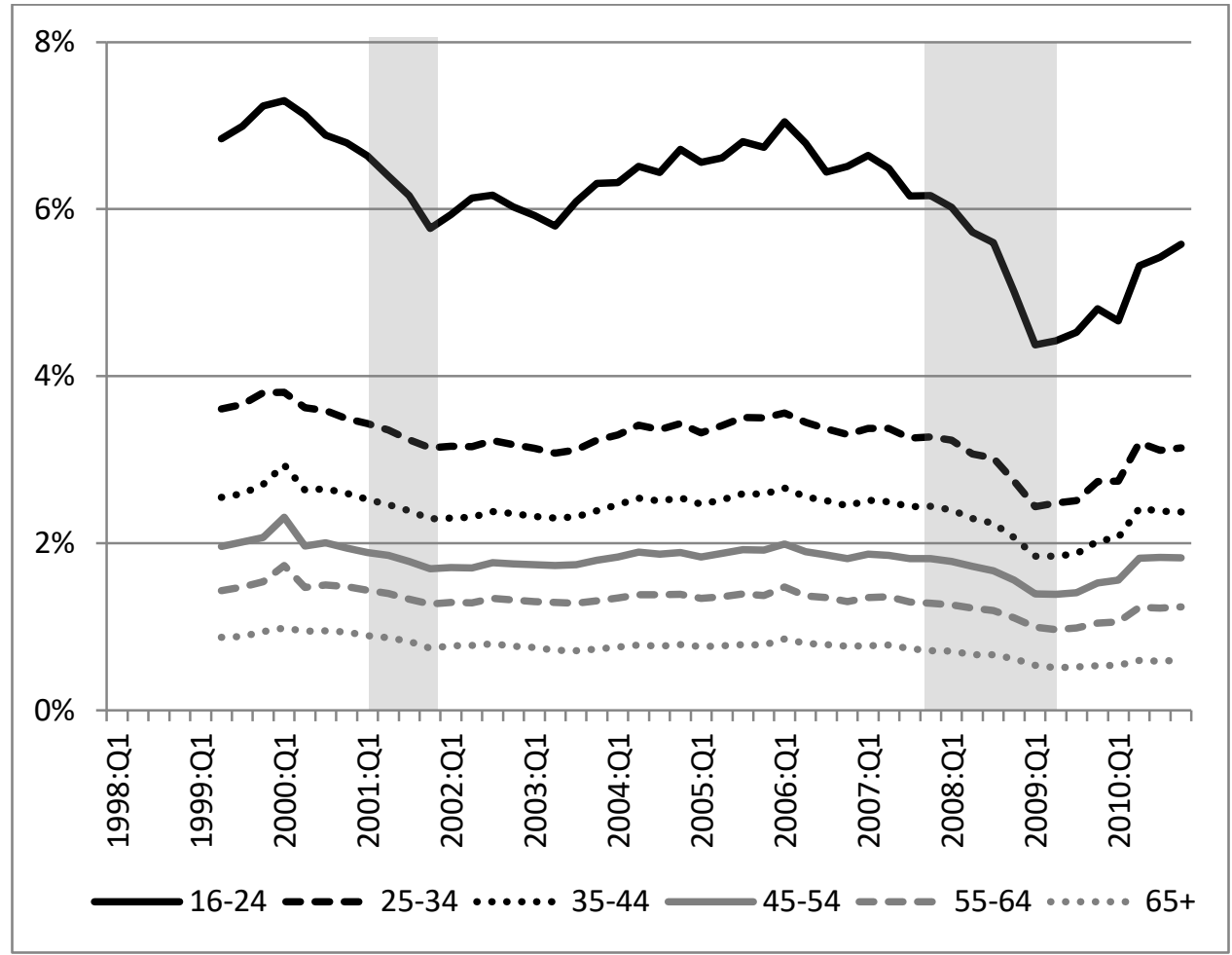

LEHD microdata, private sector.

Each series is seasonally adjusted.

Entry rates are defined in the text. 